\title{
KOMUNIKOLOŠKA INTERPRETACIJA MEDIJSKIH SADRŽAJA U HRVATSKIM TISKOVINAMA O VLADI REPUBLIKE HRVATSKE
}

\author{
Mario Plenković1, Slobodan Hadžić2, Jelena Hadžićs, Vlasta Kučí̌s", \\ Daria Mustić
}

Sveučilište u Zagrebu, Zagreb, Hrvatska \& Alma Mater Europaea - ECM \& Fakulteta za elektrotehniko, računalništvo in informatiko, Inštitut za medijske komunikacije, Univerza v Mariboru, Maribor, Slovenija ${ }^{1}$; PressCut, Zagreb, Hrvatska², Fakultet hrvatskih studija, Sveučilište u Zagrebu, Zagreb, Croatia’3; Filozofski fakultet, Sveučilište u Mariboru, Maribor, Slovenija4; Grafički fakultet, Sveučilište u Zagrebu, Zagreb, Hrvatska ${ }^{5}$

\begin{abstract}
Sažetak
Komunikološka prakseološka evaluacija medijskih sadržaja u hrvatskim tiskovinama (pisani vizualni novinski sadržaji) spram rada Vlade Republike Hrvatske i vladinih institucija, u ovom istraživanju, dala je odgovor na pitanje jesu li hrvatski tiskovni mediji ogledalo stvarnih događanja ili su iskrivljena i preoblikovana stvarnost o Vladi RH. Osnovni cilj ove longitudinalne projektne istraživačke studije je saznati kako hrvatske tiskovine svojim (ne)kritičkim autorskim pisanim i vizualnim sadržajima utječu na formiranje javnog mnijenja kod građana RH o radu i ugledu Vlade RH. Korištena je kvalitativna i kvantitativna paradigmatska ontološka, epistemiološka, aksiološka, retorička, statistička i empirijska istraživačka metodologija. Odabirom komunikološke prakseološke univerzalne istraživačke metode od pet evalvacijskih varijabli: (1) objektivnost, (2) primjerenost, (3) brzina / pravovremenost medijskih sadržaja, (4) atraktivnost $i$ (5) društvena angažiranost, $u$ evaluaciji hrvatskih tiskovina (novine $i$ vizualna produkcija) analiziran je temeljni komunikološki model javnog komuniciranja "Svi, sa svima, o svemu, potpuno, argumentirano i osobno odgovorno" na svim razinama pisane i vizualne novinske produkcije $\mathrm{u}$ hrvatskim tiskovinama u istraživačkim vremenskim granicama od 3. siječnja do 3.veljače 2021.godine. Projektno istraživanje je longitudinalnog karaktera (istraživačka studija br.1.). U ovom istraživanju autori prezentiraju samo dio istraživačkih projektnih rezultata, koji se odnose na dobivene empirijske istraživačke rezultate, koji se odnose na interpretacijsku komunikološku analizu objektivnosti, primjerenosti, brzine (pravovremenosti), atraktivnosti, te društvene angažiranosti novinskih pisanih i vizualnih evaluacijskih medijskih sadržaja. Rezultati segmentirano prezentiranih empirijskih istraživanja su pokazali visoku korelacijsku zastupljenost novinskih pisanih vizualnih medijskih sadržaja na temu Vlade i premijera Vlade $\mathrm{RH}$, te ukazuju na visoku ekstremnu zastupljenost, u pojedinačnim tiskovinama, s iracionalnim negativnim novinskim pisanim i vizualnim objavama.
\end{abstract}

\section{Ključne riječi}

Komunikologija, Vlada RH, mediji, medijski sadržaji, tiskovine, komunikološka interpretacija 


\section{PRISTUP PROBLEMU}

Aktualna povijesna medijska i politička komunikacija Hrvatske je sve više određena, uz globalnu pandemiju COVID -19 i razorne potrese (Zagreb i Petrinja), političkim, pluralističko stranačkim i medijskim različitostima, nabavkom cjepiva, traženjem potpore članica EU za ulazak u Schengen i EURO-zonu, te novim IT medijskim tehnologijama, digitalizacijom i mrežom pametne mobilne tehnologije. Buduću demokratizaciju hrvatskog društva i medijsku komunikaciju je nužno analizirati kao komunikološki proces prilagodbe nove digitalne, medijske i mobilne tehnologije. Nova medijska IT, digitalna i mobilna tehnologija afirmira izgradnju novog modela građanske participativne digitalne medijske produkcijske demokracije koja donosi nove medijske, europske i pluralističke vrijednosti. Vlada Republike Hrvatske je strateški opredijeljena za implementaciju i provedbu Nacionalne razvojne strategije Republike Hrvatske do 2030. godine. Strategija razvoja Republike Hrvatske je postavljena kao osnovni strateški razvojni cilj RH u vrijeme predsjedanja Hrvatske Vijećem EU (1.1. - 30.6.2020). Vlada Republike Hrvatske se čvrsto i strateški opredijelila za dobrobit i razvojnu budućnost građana Hrvatske do 2030.godine. Strategija razvoja RH se temelji na kooperativnim sinergijskim oblicima zajedničke suradnje svih pojedinaca, društvenih skupina, javnog i privatnog sektora, akademske i šire društvene zajednice. Strateški razvojni ciljevi RH su: (1) Konkurentno i inovativno gospodarstvo; (2) Obrazovani i zaposleni građani, (3) Učinkovito i djelotvorno pravosuđe, javna uprava i upravljanje državnom imovinom, (4) Globalna prepoznatljivost i jačanje međunarodnog položaja i uloge Hrvatske, (5) Zdrav, aktivan i kvalitetan život, (6) Demografska revitalizacija i bolji položaj obitelji, (7) Sigurnost za stabilan razvoj RH, (8) Ekološka i energetska tranzicija za klimatsku neutralnost, (9) Samodostatnost u hrani i razvoju bio gospodarstva, (10) Održiva mobilnost, (11) Digitalna tranzicija društva i gospodarstva, (12) Razvoj potpomognutih područja kao i područja $s$ razvojnim posebnostima, i (13) Jačanje regionalne konkurentnosti. Medijski sadržaji u hrvatskim tiskovinama (novine / print-mediji) $\mathrm{RH}$ očekivano su parcijalno usmjereni na kritičke osvrte, bez dubinske analize, o prijedlogu Strategije razvoja Hrvatske koja je usmjerena prema svim građanima $u$ cilju razvoja gospodarstva, javne uprave i pravosudnog sustava /1/. Zanimljiva je i komunikološka analiza tematskih prisutnosti, u medijskim sadržajima, hrvatskih vodećih novina (tiskovina / print-medija) koje se odnose na prioritete hrvatskog predsjedanja Vijećem Europske unije, a koje se odnose na četiri osnovna strateška prioriteta Hrvatske: (1) Europa koja se razvija, (2) Europa koja povezuje, (3) Europa koja štiti, i (4) Utjecajna Europa /2/. Tematske smjernice medijskih sadržaja uvodno je naglasio, predsjednik Vlade RH, mr.sc. Andrej Plenković, „Četiri prioriteta RH koja su objedinjena u motu "Snažna Europa u svijetu punom izazova", kojom se prikazuje sažeta vizija Europe koja djeluje u korist svojih država članica i njihovih građana (...) u cilju pridobivanja financijskog okvira Europske unije za razdoblje 2021. - 2027. godine" /3/.

Prezentirano istraživanje je provedeno $\mathrm{u}$ vrijeme globalne, regionalne $\mathrm{i}$ nacionalne pandemije (COVID-19) koja je odnijela veliki broj ljudskih života. Pandemija "COVID-19" prestrukturirala je države, društvo i medije u potpuno novi svijet o kojemu još premalo ili gotovo ništa ne znamo. Razotkrivaju se gospodarske, političke i medijske manipulacije na svim razinama medijske komunikacije uzrokovane virusom "Sars-CoV-2" i bolešću "COVID-19". Za neke uvažene autore "cilj medijskih i pandemijskih manipuliranja je vladanje i upravljanje ljudima u nekom novom međunarodnom globalnom svjetskom poretku" /4/. U vremenima pandemijske krize medijski sadržaji su "obojani“ imaginarno zamišljenim hermeneutičko-antropološkim kriznim oblicima "National lockdown“ upravljanja kriznom komunikacijom (gospodarstvo, jezik, ideologije, kulture, odnos 
prema samom sebi i drugima) što je obilježilo (ne)pristrane novinske medijske sadržaje koji ciljaju na autonomnu slobodu odlučivanja Vlade RH i kolateralnu refleksiju slobode razmišljanja i preuzimanja odgovornosti $u$ svijetu novih IT, digitalnih i pametnih mobilnih tehnologija koje daju novinama medijsku (ne)moć u prezentiranju novinskih sadržaja ciljanim javnostima. Publicirani novinski sadržaji u hrvatskim tiskovinama postaju nekonzistentna logička diskurzivna (ne)moć (Stožer civilne zaštite Vlade $\mathrm{RH}$ ) u percipiranju (ne)objektivne slike Vlade $\mathrm{RH} u$ relevantnim javnostima. Novinski i drugi medijski sadržaji diskurzivnu medijsku (ne)moć komunikativno (ne)objektivno interpretiraju građanima o Vladi RH, gospodarstvu, politici, strankama, građanima, oglašivačima, akademskim, interesnim i vlasničkim odnosima. Novinski medijski sadržaji postaju indikatori strateške političke, interesne, gospodarske, vlasničke, stranačke, nacionalne, regionalne, lokalne, grupne, osobne, vjerske, umjetničke, znanstvene i građanske (ne)dominacije $u$ odmjeravaju međusobnih građanskih odnosa s vladinim institucijama i Vladom RH. U tom komunikativnom interakcijskom dijalektičkom odnosu medija, građana i Vlade RH, Hrvatska je suočena s posljedicama potresa magnitude M=5.5, koji je pogodio Zagreb (glavni grad Hrvatske) i šire zagrebačko područje 22. 03. 2020. godine. Nakon snažnog razarajućeg potresa uslijedili su brojni naknadni potresi u vremenu od 22. 03. do 14. 04. 2020.godine, što je dodatno građanima i Vladi RH, uz progresivno širenje virusa "COVID-19", otvorilo nove dodatne probleme $u$ vođenju i kriznom upravljanju državom i obnovom Zagreba kao i porušenim područjima i naseljima $u$ širem okruženju Zagrebačke i Krapinsko zagorske županije. Krizna državna upravljačka komunikacija za Vladu RH se iznenadno usložnjava, novim katastrofalnim potresom u Petrinji. „U ponedjeljak 28. prosinca 2020. godine u 6 sati i 28 minuta potres magnitude 5.0 prema Richteru, s epicentrom nedaleko Petrinje, snažno je zatresao područje središnje Hrvatske intenzitetom VII stupnja EMS ljestvice, a osjetio se i u susjednim državama.
Isto jutro na istom epicentralnom području uslijedila su još dva jača potresa. Prvi u 7 sati i 49 minuta magnitude 4.7 prema Richteru intenziteta VII stupnja, a drugi dvije minute kasnije magnitude 4.1 prema Richteru intenziteta VI stupnja EMS ljestvice. (...). Na žalost, svi navedeni potresi bili su samo niz predudara (foreshocks) prije glavnog koji se dogodio dan kasnije, u utorak 29. prosinca 2020.) u 12 sati i 19 minuta. Epicentar ovog razornog potresa magnitude 6.2 prema Richteru bio je 5 kilometara jugozapadno od Petrinje sa žarištem na dubini od $11.5 \mathrm{~km}$, ocjenjen intenzitetom VIII - IX stupnja EMS ljestvice" /5/. Analizirajući novinske medijske sadržaje, posebnu komunikološko-analitičku pozornost, u vremenima krizne komunikacije, analitički je opserviran rad "Stožera civilne zaštite $\mathrm{RH}^{\prime \prime} \mathrm{i}$ na nastale poteškoće $\mathrm{u}$ pridobivanju cjepiva prema hodogramu $i$ dogovoru o distribuciji cjepiva u državama članicama Europske unije. U vrijeme istraživanja komparirani su novinski i drugi medijski sadržaji o (ne)kritičkim napadima oporbenih stranaka na "Stožer civilne zaštite $\mathrm{RH}^{\prime \prime} \mathrm{i}$ nastale poteškoće $\mathrm{u}$ distribuciji cjepiva, koji su oscilirali od (ne)objektivnosti do (i)racionalnih medijskih napada na Vladu $\mathrm{RH}$. Razvidno je da komunikološka interpretacija medijskih sadržaja $\mathrm{u}$ hrvatskim novinskim sadržajima $\mathrm{u}$ odnosu na Vladu $\mathrm{RH}$, s komunikološkog vidika, otvara brojna društvena, humanistička i etička pitanja medijskih sloboda, socijalne jednakosti, tolerancije, društvene pravednosti, solidarnosti, blagostanja, zdravlja, mira, suživota i upravljanja kriznom državnom, političkom i medijskom komunikacijom. Vlada $\mathrm{RH}$ je suočena $\mathrm{s}$ fenomenom nove nepredvidljive stohastične globalne, regionalne, nacionalne $\mathrm{i}$ lokalne krizne korona komunikacije. Komunikološka interpretacija publiciranih novinskih sadržaja o Vladi RH, politici, strankama, izborima, pandemiji, iznenadnim katastrofama, turizmu, koruptivnim aferama, itd., je pokazala ciljane (ne)kritičke i (ne) objektivne novinske sadržaje koji snažno utječu na građansko ponašanje, odlučivanje i (pred)izborno građansko opredjeljenje. 
Empirijsko istraživanje novinskih sadržaja u hrvatskim tiskovinama (print-medijima) smo ciljano usmjerili na spoznajnu korelaciju o mogućem utjecaju novinskih sadržaja na stavove i mišljenja građana o Vladi RH, na svim razinama nacionalne, županijske, gradske i lokalne medijske i političke komunikacije.

\section{NOVINSKI PISANI I VIZUALNI MEDIJSKI SADŽAJI U KORELACIJI S RADOM I UGLEDOM VLADE RH}

Poznata je M.McLuhanova komunikološka uzrečica „medij je poruka“. Uzrečica je smislena ukoliko se dovedu u korelaciju medij i medijski sadržaji. Između medija i medijskih sadržaja, kao i oblika komuniciranja, postoji stanovita sukladnost $\mathrm{i}$ uvjetovanost $\mathrm{u}$ kvalitativnom i kvantitativnom pogledu. Osnovno je pravilo medijske komunikacije smanjenje neizvjesnosti u javnom komuniciranju. Za učinkovito prenošenje medijskih sadržaja je nužno medijske sadržaje kodirati u sustav komuniciranja koji je zajednički komunikatoru (autoru medijskih sadržaja) i recipijentima (građanima kao primateljima medijskih sadržaja). Ista komunikološka zakonitost vrijedi u komuniciranju Vlade $\mathrm{RH}$ s građanima. Novinska komunikacija (tiskovine i printmediji), kao podsustav javnog komuniciranja, se povijesno najprije razvila. Ona datira $u$ svjetskim relacijama od izuma tiska (Gutenberg, 1455.g.). Komunikacijske učinke novinske komunikacije $\mathrm{u}$ javnostima možemo promatrati s dva stajališta: (1) sa stajališta karakterističnih obilježja komunikatora / novinara (vlasnika medija) i (2) i sa stajališta izražajnih obilježja novinskih medijskih sadržaja. Komunikološka interpretacija novinskih sadržaja polazi od općih pretpostavki koje moraju zadovoljavati svi tvorci medijskih sadržaja (komunikatori / novinari) $\mathrm{u}$ tiskovinama (specifična novinarska znanja, komunikacijske vještine te novinarsku kulturu i etiku komuniciranja). U analizi medijskih sadržaja nužno je uvijek polaziti od pretpostavke utjecajne (ne)moći komunikacijsko-novinarskih mogućnosti u novinskom izrazu /6/. Medijsku komunikaciju sve više određuju nove medijske IT tehnologije, digitalizacija i snažan razvoj pametne mobilne tehnologije. Provedeno empirijsko istraživanje korelacijski promatra novinske medijske sadržaje (tiskovine i print-medije) u odnosu na stratešku politiku Vlade RH i njihov utjecaj na građansko ponašanje na svim nacionalnim, županijskim, gradskim i lokalnih razinama komuniciranja. „Vlada RH obavlja izvršnu vlast $u$ skladu s Ustavom i zakonom. $U$ obavljanju izvršne vlasti Vlada određuje, usmjerava i usklađuje provedbu politika i programa, te $\mathrm{u}$ tu svrhu predlaže $\mathrm{i}$ donosi strategije, daje smjernice, donosi akte, te poduzima druge mjere potrebne za uređenje odnosa iz područja svoje nadležnosti. Vlada RH predlaže Hrvatskom saboru zakone i druge akte, te državni proračun i završni račun, provodi zakone i druge odluke Hrvatskoga sabora, donosi uredbe za izvršenje zakona, vodi vanjsku i unutarnju politiku, usmjerava i nadzire rad državne uprave, brine o gospodarskom razvitku zemlje, usmjerava djelovanje i razvitak Hrvatske. Predsjednik Vlade mr.sc. Andrej Plenković je izabran u dva mandata na čelo Vlade Republike Hrvatske (2016. - 2024.). Zajedno s članovima Vlade odgovoran je za odluke koje Vlada donosi, a Vlada je odgovorna Hrvatskom saboru. Članovi Užeg kabineta su predsjednik i dva potpredsjednika Vlade. Ministarstva Republike Hrvatske su: Ministarstvo financija, Ministarstvo rada, mirovinskoga sustava, obitelji i socijalne politike, Ministarstvo obrane, Ministarstvo znanosti i obrazovanja, Ministarstvo turizma i sporta, Ministarstvo mora, prometa i infrastrukture, Ministarstvo poljoprivrede, Ministarstvo unutarnjih poslova, Ministarstvo gospodarstva i održivog razvoja, Ministarstvo prostornoga uređenja, graditeljstva i državne imovine, Ministarstvo zdravstva, Ministarstvo pravosuđa i uprave, Ministarstvo hrvatskih branitelja, Ministarstvo regionalnoga razvoja i fondova Europske unije, Ministarstvo kulture i medija i Ministarstvo vanjskih i europskih poslova /7/. Program Vlade RH (2020.- 2024.) se temelji na osnovnim polazištima i prioritetnim ciljevima: 
Socijalna sigurnost (Zdrava, solidna i pravedna Hrvatska), (2) Perspektivna budućnost (Konkurentna, vitalna i obrazovana Hrvatska), (3) Ekonomska suverenost (samodostatna, održiva i zelena Hrvatska) (4) Osnažena Hrvatska (Učinkovita, otporna i digitalna Hrvatska), i (5) Globalna prepoznatljivost (Ponosna, sigurna i utjecajna Hrvatska). U programskim okvirima „Perspektivna budućnost Hrvatske" strateški se planira zakonsko i društveno prilagođavanje i usklađivanje medijske regulative $\mathrm{RH}$ smjernicama i direktivama EU. Program Vlade RH ciljano predviđa ,jačanje povjerenja $u$ medije poticanjem veće transparentnosti, odgovornosti i integriteta. Štitit će se temeljne slobode i načela novinarstva i osigurati daljnji razvoj medija. Donijet će se novi Zakon o elektroničkim medijima. Zakonom će se potaknuti transparentnost poslovanja, pogotovo vlasništva pružatelja elektroničkih usluga. Osigurat će se veća razina transparentnosti izvora financiranja, kao i financiranje iz državnih i javnih tijela vlasti i poduzeća, kao i javna objava vlasničkih struktura, podataka o financiranju i dostavi izvadaka

iz državnih registra. Uspostavit će se novi poticajni okvir za daljnji razvoj elektroničkih medija u skladu s vrlo brzim tehnološkim razvojem i potrebama prilagodbe suvremenim trendovima te će se pripremiti novi Zakon o elektroničkim medijima koji je već prošao javnu raspravu. Donijet će se Izmjene Zakona o medijima i predložiti model potpore distribuciji tiskanih medija. Nastavit će se poticati i razvijati javne medije - Hrvatsku radioteleviziju i HINA-u osiguravajući im neovisnost i stabilno financiranje. Ulagat će se u povećanje dostupnosti usluga elektroničkih medija osobama s invaliditetom. Omogućit će se financiranje nastavka programa poticanja kvalitetnog novinarstva putem Agencije za elektroničke medije, a poticat će i razvijati programe medijske pismenosti“ /8/. Vlada HR i novine (tiskovine i print-mediji) se nalaze $u$ kontinuiranom dvosmjernom komunikacijskom procesu (ne)diskurzivne kompetitivnosti, suočavanja i odmjeravanja moći gdje svaki subjekt (Vlada RH i tiskovine) žele kontinuirano dokazivati svoje umne, kulturne, političke, gospodarske, umjetničke, znanstvene, nacionalne, županijske, gradske i lokalne političke i medijske superiornosti.

\section{EVALVACIJA NOVINSKIH PISANIH I VIZUALNIH MEDIJSKIH SADRŽAJA}

Komunikološka teorija evaluacije javnog komuniciranja se sve više orijentira na stavove i uvjerenja primatelja medijskih sadržaja, to jest, na komunikacijski proces interiorizacije primljenih medijskih sadržaja. Komunikolozi su uočili da je u holističkom procesu javnog komuniciranja najvažnije saznati kakve stavove posreduju medijski sadržaji i kako oni utječu na formiranje javnog mnijenja. Brojni medijski komunikolozi, posebno nove komunikološke škole u institutima za istraživanje javnog mnijenja, zagovaraju komunikološku interiorizaciju $\mathrm{u}$ komunikacijskom procesu posredovanja medijskih sadržaja u tiskovinama. Jedan od najpoznatijih instituta za ispitivanje javnog mnijenja je Gallupov „Institute for Public Opinion". Osnivač američkog Instituta za javno mnijenje je George Gallup (1901.-1984.) u Princetonu, New Jersey. G. Gallup je 1935.g. je proširio, na globalnim svjetskim razinama, istraživačku mrežu od 40 jedinica za istraživanje javnog mnijenja i masovnih komunikacija. Po uzoru na Gallupov institut istraživanje masovnih komunikacija (medijskih sadržaja) se sve više razvijalo na svim razinama globalne, regionalne, nacionalne i lokalne razine istraživanja javnog mnijenja i masovnih komunikacija (medija i medijskih sadržaja). Istraživanje medijskih sadržaja je postupak raščlambe svih oblika pisanih tekstova i drugih vizualnih oblika $\mathrm{u}$ tiskovinama (print-medijima). Analiza pisanih i vizualnih sadržaja (fotografija) u tiskovinama se zasniva na evalvacijskom kriterijskom postupku promatranja $\mathrm{i}$ analizi medijskih sadržaja u tiskovinama. U analizi sadržaja tiskovina je ključno komunikološko pitanje kako i na koji način definirati kriterijski evaluacijski pristup „fundamentum divisionis" (načelo osnovne diobe za 
evaluacijski postupak), to jest osnovne kriterije evaluacije. U analizi medijskih sadržaja ugledni komunikolozi (Lazarsfeld i Berelson)" su smatrali da je dovoljno analizirati medijske sadržaje s tri glavna aspekta: (1) s aspekta pojedinih karakterističnih sadržaja tiskovina (print-medija), (2) s aspekta autora tekstova, i (3) s aspekta publike koja korespondira $\mathrm{s}$ novinskim sadržajima. Najveći problem $\mathrm{u}$ analizi novinskih medijskih sadržaja je određivanje uzorka, to jest, što analizirati, $u$ kojim vremenskim granicama i kada? Ukoliko se ne odrede precizni kriteriji i definira što je "fundamentum divisionis" postupak analize medijskih sadržaja postaje nelogičan, anarhičan i bez učinkovitih rezultata /9/. Nikada nijedna komunikološka teorijska tvrdnja nije apsolutna već je ona uvijek umijeće postavljanja racionalnih teorijskih kriterija koji vode učinkovitom evaluacijskom postupku $\mathrm{u}$ interpretaciji medijskih sadržaja. „Stvaralačka produkcija medijskih sadržaja predstavlja izvorni, originalni, neponovljivi akt kreativnog medijskog čovjeka (komunikator / novinar). Ona uključuje problematiku razložne diseminacije medijskih sadržaja, dokazivanje, nagovaranje, opovrgavanje, edukaciju, animaciju, kodiranje i dekodiranje plasiranih informacija medijskim javnostima. Medijska komunikacija je komunikacijski proces transformiranja medijskih spoznaja kao informacije per se u informaciju per me, odnosno per nos, (...). Medijsko komuniciranje je izvorni dijalektički komunikacijski proces u kojem su svi sudionici komunikatori a ujedno i recipijenti. (...). Postavlja se temeljno komunikološko vrijednosno pitanje: „, Kakav je vrijednosni učinak medijskih poruka (medijskih sadržaja)“? Je li moguća evaluacija (vrednovanje) informacijskih i komunikacijskih produkcijskih medijskih sadržaja? S komunikološkog gledišta otvara se osnovno strateško komunikološko pitanje: kako i na koji način, te koja je tehnologija pridobivanja povratne evaluacijske informacije (feedbacka)? Komunikološka teorija i praksa podrazumijeva tri različite vrste evaluacije medijskih sadržaja: Informacijska, komunikacijska i prakseološka evaluacija (vrednovanje). (...) Što je evaluacija (vrednovanje) medijskih sadržaja ? /10/. Komunikacijsku evaluaciju medijskih sadržaja možemo promatrati s aspekta Nietzscheova aforizma: "Za sve ono što čovjek propušta da postane vidljivo, možemo se pitati: što se želi sakriti?". Komunikologija kao znanost o komuniciranju, s aspekta metodologije medijskih istraživanja, $\mathrm{s}$ posebnom pažnjom pristupa evaluaciji medijskih sadržaja $u$ cjelokupnom posredovanom informacijskokomunikacijskom holističkom medijskom procesu. Sustavna medijska istraživanja nastoje, u skladu s novim evaluacijskim komunikološkim istraživanjima, da što preciznije predvide output učinka komunikacijskih poruka (medijskih sadržaja) javnostima. Poznata je Mannheinova metodologija /11/ koja nastoji pokazati da elementi poremećaja istine "sami po sebi", na poseban način, imaju svoju učinkovitu komunikacijsku vrijednost. Nije moguće društvene stvari upoznati samo izvana, treba u njima sudjelovati da bi se poruka medijskih sadržaja razumjela. Za učinkovitu komunikacijsku evaluaciju medijskih sadržaja nužno je istaknuti ulogu uvjeravanja (uvjeravačke komunikacije / persuazije). Komunikacijsko uvjeravanje je medijski proces kojim se koriste mediji kako bi svojim medijskim sadržajima nametnuli javnosti svoje poruke u medijskim sadržajima. Osnovna zakonitost komunikacijske evaluacije medijskih sadržaja je znati i moći komunicirati po principu: svi, sa svima, o svemu, potpuno, argumentirano i osobno odgovorno /12/. U istraživanju medijskih sadržaja u tiskovinama, uvažavajući informacijske i komunikacijske teorijske metode za evaluaciju novinskih sadržaja, korištena je prakseološka metoda evaluacije medijskih sadržaja u tiskovinama. Prakseološka evaluacija je, s komunikološkog vidika, istraživački složena metoda za objektivnu prosudbu svih oblika medijske i javne komunikacije. Prakseologija je opća znanost o uspješnom, učinkovitom djelovanju na svim područjima medijske i ljudske egzistencije (fizičkom, intelektualnom, estetskom i umjetničkom) koju je utemeljio T.Kotarbinski /13/. Osnovni zadatak 
prakseološle metode je da formulira kriterije i mjerila (varijable) za interpretativnu evaluaciju medijskih sadržaja $\mathrm{u}$ hrvatskim tiskovinama. Odabirom komunikološke prakseološke univerzalne evaluacijske metode /14/ od pet varijabli: (1) objektivnost, (2) primjerenost, (3) brzina / pravovremenost medijskih sadržaja, (4) atraktivnost i (5) društvena angažiranost, u evaluaciji novinske print-produkcije regulacije afirmiran je temeljni model javnog komuniciranja "svi, sa svima, o svemu, potpuno, argumentirano i osobno odgovorno" na svim razinama novinske print-produkcije.

\section{PRIMJENJENA METODOLOGIJA METODE ISTRAŽIVANJA}

U ovom istraživanju je provedena genetskostrukturalna metodološka sadržajna metoda evaluacije novinskih pisanih $i$ vizualnih sadržaja koji su publicirani u $(\mathbf{N}=40)$ hrvatskih tiskovina, u vremenskim istraživačkim granicama (T: 03.01. - 03.02.2021.), koji su svojim pisanim i vizualnim sadržajima interpretirali rad Vlade $\mathrm{RH}$ čitateljskim javnostima. Istraživanje je provedeno prakseološkom metodom analize novinskih sadržaja (N1 = 296) pisanih i vizualnih (fotografije i karikature) o jednomjesečnom radu Vlade $\mathrm{RH} u$ jednomjesečnom vremenskom intervalu od 3.siječnja do 3.veljače 2021.godine. Na osnovu komunikoloških spoznaja, analizirajući brojna dosadašnja srodna istraživanja novinskih sadržaja, postavljena je temeljna istraživačka hipoteza (TH1): Jesu li hrvatske print medijske tiskovine ogledalo stvarnih događanja ili su iskrivljena $\mathrm{i}$ preoblikovana stvarnost o Vladi RH, s aspekta publiciranih novinskih pisanih i vizualnih sadržaja (fotografije i karikature) o Vladi RH, hrvatskim građanima i ciljanim javnostima ? Empirijsko istraživanje je propitivalo i druge pomoćne hipotetske istraživačke pretpostavke, i to: (H2) - Koliko interpretacijski stavovi (autora) pisanih i vizualnih novinskih sadržaja utječe na mišljenja i stavove građana o Vladi RH?; (H3) - Koliko su novinski sadržaji u autorskim interpretacijama objektivni $\mathrm{u}$ prenošenju poruka građanima o
Vladi RH?; (H4) - Jesu li novinski sadržaji primjereni ugledu i funkciji Vlade RH?; (H-5) Koliko je aktualna vremenska brzina, publiciranih novinskih pisanih i vizualnih sadržaja o Vladi RH, relevantna za život, rad i stvaralaštvo građana Hrvatske?; (H-6) - Jesu li novinski sadržaji interpretacijski komunikativno atraktivni građanima za razumijevanje odluka, mjera, zakona i reformi koje predlaže Vlade RH?; (H-7) - U kojim su interpretacijskim relacijama (vrijednosnim, vlasničkim ili stranačkim) hrvatske tiskovine sadržajno prepoznatljivo angažirane $u$ tumačenju i prezentaciji ugleda i rada Vlade $\mathrm{RH}$ građanima Hrvatske? i (H-8) - Kao zaseban istraživački cilj postavljeno je pitanje medijske pojavnosti Vlade Republike Hrvatske u cjelokupnom prostoru hrvatskih tiskovina (pisanih i vizualnih). Frekventnost pojavljivanja su korelacijski omjeri ukupnog obima medijskog prostora $\mathrm{u}$ tiskovinama Republike Hrvatske. Sukladno pravilima longitudinalnih istraživanja, promatraju se pomaci $u$ frekvencijskim pokazateljima kroz zadana i komparabilna razdoblja longitudinalnog istraživanja. Promatranje parametara unutar izdvojenog uzorka od populacije print medija bit će prikazana metodom statističke analize; i (H-9) - Posebno istraživačko pitanje se odnosi na detektiranje osobe koja se, u sklopu izdvojenog korpusa novinskih medijskih objava najviše pojavljuje, odnosno osoba koju unutar članaka koji govore o Vladi RH se u tiskovinama najviše spominje? Odabrana metodologija i metode istraživanja su sadržajno orijentirane na procjenu stavova i mišljenja autorske (novinara i komunikatora) interpretacije $u$ novinskim sadržajima o Vladi HR $\mathrm{u}$ analiziranim vremenskim granicama od 3.01. do 03.02.2021. godine. Holističkostohastički dinamički uzorak ( $U=40)$ empirijski je analizirao i evaluacijski interpretirao hrvatske tiskovine koje su svojim sadržajima interpretirali rad, ugled i aktivnosti Vlade RH: Jutarnji list, Novi list, Večernji list, Slobodna Dalmacija, Glas Slavonije, Glas Istre, 24 sata; Zadarski list, The Economist Croatia, Poslovni dnevnik, Nacional, Lider, Glas grada, 7 Dnevno, Glas Podravine, Novosti, 24 Express, 
Posavska Hrvatska, Globus, 7 Plus Regional, Međimurske novine, Zagorje international, Hrvatska elekroprivreda, Hrvatski tjednik, Školske novine, Hrvatski umirovljenički list, Vukovarske novine, Dnevnik, Veritas, Varaždinske vijesti, Građevinar, Prilika, Vijenac, Dobra kob, Vinkovački list, Bjelovarski list, Požeško-slavonska kronika, Gospodarski list, Hrvatski glasnik i Moslovački list. Analizirani istraživački uzorak nije preferencijski odabran već je odabir uzorka slijedom realne vremenske dinamike objavljivanja novinskih sadržaja (pisanih i vizualnih) o radu, ugledu i aktivnostima Vlade RH. Primijenjena metodologija i odabrane komunikološke istraživačke metode su odabrane na temelju provedenih srodnih komparativnih medijskih istraživanja i relevantne metodološke i komunikološke recentne literature /15/ U provedenom istraživanju korištena je kvalitativna i kvantitativna paradigmatska ontološka, epistemiološka, aksiološka, retorička, statistička i empirijska metodologija /16/ Osnovni cilj ove longitudinalne projektne istraživačke studije je bilo saznati kako hrvatske tiskovine svojim (ne)kritičkim autorskim pisanim i vizualnim sadržajima utječu na formiranje javnog mnijenja kod građana $\mathrm{RH}$ o radu i ugledu Vlade RH. Poseban istraživački cilj rada je detektiranje novinske pojedinačne percepcije o radu, aktivnostima i ugledu Vlade RH u vremenima strateškog kriznog upravljanja državom na svim razinama globalne, regionalne, nacionalne i lokalne državne uprave. Krizno upravljanje državom u nepredvidljivim događanjima i prirodnim katastrofama (globalne pandemije, upravljanje državnim institucijama, stožer civilne zaštite, iznenadni katastrofalni potresi, (ne)reforme, oprečni stavovi vladajućih i političke oporbe, balansirano zatvaranja ugostiteljskih usluga, lockdown, problemi u gospodarstvu, društveni, politički, znanstveni, politički, stranački, koruptivno predizborni prijepori, kao i druga aktualna događanja) su odraz pisanih i vizualnih novinskih (ne)kritičkih i (ne)pristranih sadržaja o radu, ugledu i aktivnostima Vlade RH. Sadržajno (ne)programirane pro et contra publiciranje novinskih poruka o Vladi $\mathrm{RH}$, na svim razinama tiskane medijske komunikacije, utjecalo je na stvaranje (ne)programiranih utjecajnih oblika interiorizacije na javno mnijenje hrvatskih građana, što je rezultiralo formiranjem građanske pozitivne, negativne ili neutralne percepcijske slike o radu, ugledu i aktivnostima Vlade RH.

Glavni istraživački zadatak ove projektne longitudinalne komunikološke studije je saznati najfrekventnija mišljenja i stavove autora (novinara i komunikatora) $\mathrm{u}$ hrvatskim tiskovinama (print - medijima) o radu, ugledu i aktivnostima Vlade RH koja upravlja državom u izbornom mandatnom razdoblju od 2020. do 2024.godine.

Poseban istraživački zadatak je bila usporedba dobivenih rezultata $\mathrm{s}$ provedenim istraživanjima u okviru longitudinalnog znanstveno-istraživačkog projekta „Strateški komunikacijski management: Paradigmatska promišljanja o kulturi medija i odnosima $\mathrm{s}$ javnostima" (Alma Mater Europaea - EASA, Maribor, Slovenija) /17/. U radu nije bilo moguće primijeniti komunikološku imanentnu istraživačku metodu analize hrvatskih novinskih sadržaja u cilju dubljih shvaćanja i slojevite analize izraženih mišljenja i stavova o radu, ugledu i aktivnostima Vlade $\mathrm{RH} u$ hrvatskim tiskovinama. Komunikološka novinska sadržajna interpretacija pisanih i vizualnih sadržaja je izvedena metodom komunikološke dubinske sadržajne analize, uz puno uvažavanje osnovnih principa novinarske profesije, što podrazumijeva visoke profesionalne i etičke novinarske standarde, $\mathrm{u}$ postupku oblikovanja novinskih pisanih i vizualnih sadržaja. Na temelju pet osnovnih principa novinarske i komunikološke izražajne retorike: (1) objektivnost, (2) primjerenost, (3) brzina komuniciranja, (4) atraktivnost i (5) autorska angažiranost izvršena je sustavna evaluacija novinskih sadržaja na uzorku od $(\mathrm{N}=40)$ hrvatskih tiskovina. Dodatno je izvršena sadržajna novinska procjena stavova i mišljenja hrvatskih tiskovina o Vladi RH u vremenu od 03.siječnja do 03.veljače 2021.godine. Odabrana komunikološka metoda za analizu pisanih i 
vizualnih novinskih sadržaja je sustavno interpretirala komunikološko-novinarske kategorije: (1) objektivnosti kao kategoriju istinitosti pisanih $\mathrm{i}$ vizualnih novinskih sadržaja; (2) primjerenost, uz puno uvažavanje novinskog diskursa, kao (ne)moć logičke komunikativne argumentacije; (3) brzina novinskih poruka $u$ prezentu događanja i brzine diseminaciju novinskih poruka o svakodnevnom uvidu i praćenju rada $i$ aktivnosti Vlade RH; (4) atraktivnosti u analizi novinskih sadržaja kao spoznajna kontinuirana motivacija građana i čitateljske javnosti da aktivno prate i kritički propituju rad i aktivnosti Vlade RH; (5) angažiranost novinskih sadržaja koja polazi od prava građana na informaciju o radu i aktivnostima Vlade $\mathrm{RH}, \mathrm{u}$ cilju ostvarivanja i poštivanja autorske slobode (novinara / komunikatora), bez indoktrinacije, ideologizacije, alijenacije, stranačke preferencije i (ne)kritičke viktimizacije čitateljske publike i Vlade RH. Na temelju provedene komunikološke analize novinskih sadržaja izvršena je interpretacijska diskurzivna retorička interpretacija hrvatskih tiskovina o radu, aktivnostima i ugledu Vlade $\mathrm{RH} u$ zadanim istraživačkim kriznim vremenskim granicama. Istraživanje se longitudinalno komparativno nastavlja od 10.travnja do 10.svibnja 2021.g i od 10.listopada do 10 . studenoga 2021.g. Komunikološka interpretacija dobivenih projektnih rezultata, po završetku istraživanja, se usporedno komparativno analizira s projektnim dobivenim rezultatima o radu, aktivnostima i ugledu Vlada u susjednim državama (Austrija, Italija, Hrvatska, Mađarska i Slovenija) u okviru projekta „Strateški komunikacijski management: Paradigmatska interpretacija i promišljanja o kulturi medija i odnosima $\mathrm{s}$ javnostima"/18/.

\section{INTERPRETATIVNE RELACIJE ZA DETEKCIJU STAVOVA I MIŠLJENJA U HRVATSKIM TISKOVINAMA O VLADI RH}

Komunikološki postupak validacije provedene analize evaluacijskih novinskih sadržaja u hrvatskim tiskovinama o stavovima i mišljenjima novinskih pisanih i vizualnih sadržaja o Vladi RH se temelji na temelju devet izoliranih hipotetskih pitanja koja su analizirana u ovom istraživanju, i to:

1. Jesu li hrvatske tiskovine (print-mediji) ogledalo stvarnih događanja ili su iskrivljena i preoblikovana medijska stvarnost o radu i aktivnostima Vlade $\mathrm{RH}$ ?

2. Koliko interpretacijski stavovi (autora) novinskih pisanih i vizualnih sadržaja utječu na mišljenja i stavove građana o Vladi RH?

3. Koliko su novinski sadržaji u autorskim interpretacijama objektivni u prenošenju poruka o Vladi RH građanima Hrvatske?

4. Jesu li novinski sadržaji u stavovima i mišljenjima primjereni ugledu, radu, aktivnostima i funkciji Vlade RH?

5. Koliki je vremenski protok (brzina) publiciranih novinskih sadržaja o Vladi RH relevantna za život, rad i stvaralaštvo građana Republike Hrvatske ?;

6. Jesu li novinski sadržaji u hrvatskim tiskovinama interpretativno i komunikativno atraktivni građanima za razumijevanje odluka, mjera i reformi koje donosi Vlada RH?

7. U kojim su interpretacijskim relacijama (vrijednosnim, vlasničkim ili stranačkim) hrvatske tiskovine prepoznatljive svojim angažiranim komunikološkim interpretacijama $\mathrm{u}$ informiranju i tumačenju čitateljskim javnostima rad, ugled, aktivnosti, ulogu i funkciju Vlade $\mathrm{RH}$ ?

8. Kolika je medijska frekvencijska pojavnosti Vlade RH u cjelokupnom prostoru hrvatskih tiskovina $\mathrm{s}$ aspekta ukupnog obima medijskog prostora $\mathrm{u}$ tiskovinama $\mathrm{u}$ vrijeme trajanja longitudinalnog projektnog istraživanja?

9. Koji se dužnosnici Vlade $\mathrm{RH}$ najviše frekvencijski detektiraju, spominju i pojavljuju sadržajno u hrvatskim tiskovinama?

U metodološkom pogledu postavlja se temeljno komunikološko pitanje kako, i na koji način, i s kojim komunikološkim postupcima, to jest, kojim izvedbenim slojevitim analitičkim sadržajno vjerodostojnim postupcima i 
metodama detektirati osnovne profesionalne i etičke principe novinarske profesije $\mathrm{u}$ odnosu na stavove i mišljenja prema Vladi RH u hrvatskim tiskovinama? U istraživanju odabrali smo pet metoda za detektiranje temeljnih komunikoloških profesionalnih evaluacijskih principa javnog komuniciranja $\mathrm{u}$ hrvatskim tiskovinama, i to:

1. Novinska pisana i vizualna objektivnost;

2. Primjerenost novinskih medijskih sadržaja;

3. Pravovremenost (brzina publiciranja) i dostupnost javnosti relevantnih novinskih sadržaja o radu, ugledu, aktivnostima i funkciji Vlade RH;

4. Sadržajna medijska novinska pisana i vizualna atraktivnost o Vladi $\mathrm{RH}$;

5. Autorska (ne)progresivna sadržajna novinska pisana i vizualna angažiranost »pro et contra« o radu i funkciji Vlade RH.

$\mathrm{Na}$ temelju postavljenih devet interpretativnih relacija za detekciju stavova i mišljenja o radu, ugledu, aktivnostima i funkciji Vlade RH, kao i na temelju pet postavljenih evaluacijskih metoda za detekciju komunikoloških profesionalnih principa $u$ novinskim pisanim i vizualnim sadržajima polučeni su zanimljivi istraživački interpretativni rezultati.

\begin{tabular}{|c|c|}
\hline Naziv teme & Opis teme \\
\hline Vlada RH & $\begin{array}{l}\text { svako spominjanje općenitog pojma 'Vlada RH', sjednice Vlade RH } \\
\text { (izvještaji) i odluke Vlade RH. Svaki spomen predstojnika Ureda PVRH, } \\
\text { g. Zvonimir Frka-Petešić }\end{array}$ \\
\hline Premijer & $\begin{array}{l}\text { svako spominjanje Andreja Plenkovića, izjave i intervjui Premijera. } \\
\text { Samo izvorne vijesti. }\end{array}$ \\
\hline Sjednice Vlade & sve o sjednicama Vlade; Samo izvorne vijesti, komentari \\
\hline Potpredsjednici & $\begin{array}{l}\text { Svako spominjanje Davor Božinović, Zdravko Marić, Tomo Medved, } \\
\text { Boris Milošević }\end{array}$ \\
\hline Ministarstvo branitelja & $\begin{array}{l}\text { svako spominjanje: Tomislav (Tomo) Medved, ministar (ujedno i } \\
\text { umirovljeni brigadni general Hrvatske vojske), ministarstvo - važni } \\
\text { članci, puni sadržaj; }\end{array}$ \\
\hline Ministarstvo financija & $\begin{array}{l}\text { svako spominjanje: Zdravko Marić, ministar, ministarstvo - važni } \\
\text { članci, puni sadržaj; }\end{array}$ \\
\hline $\begin{array}{l}\text { Ministarstvo gospodarstva i } \\
\text { održivog razvoja }\end{array}$ & $\begin{array}{l}\text { svako spominjanje: Tomislav Čorić, ministar, ministarstvo - važni } \\
\text { članci, puni sadržaj }\end{array}$ \\
\hline
\end{tabular}

\section{KVANTITATIVNA FREKVENCIJSKA METODA MEDIJSKE POJAVNOSTI VLADE RH U HRVATSKIM TISKOVINAMA}

$\mathrm{U}$ istraživanju je primijenjena kvantitativna frekvencijska metoda medijske analize novinskih pisanih i vizualnih sadržaja $u$ hrvatskim tiskovinama.

Uzorak se sastoji od $(\mathbf{N 1}=6379)$ članaka objavljenih $\mathrm{u}$ hrvatskim tiskovinama $\mathrm{u}$ vremenskom granicama $(\mathrm{T} 2=1.1 .2021$. do 2.3.2021.)

Za izdvajanje objavljenih medijskih sadržaja korišteni su napredni kriteriji pretrage sadržaja prema definiranim temama (prikaz tema i opisa tema koji su prezentirani u tabličnom prikazu (1). Ukupno pronađeni novinski sadržaji kategorizirani su u 20 različitih tematskih sadržaja. Svojim sadržajem teme odvajaju članke koji se odnose na: Vladu RH, Premijera, Ureda Predsjednika Vlade, sjednica Vlade kao događaja, podpredsjednika Vlade i svakog pojedinog Ministarstva. Prilikom izdvajanja članaka $\mathrm{u}$ analiziranom uzorku, uz spominjanje pojedinog Ministarstva, uključeno je i spominjanje ministra / ministrice. 


\begin{tabular}{|c|c|}
\hline $\begin{array}{l}\text { Ministarstvo prostornoga uređenja, } \\
\text { graditeljstva i državne imovine }\end{array}$ & $\begin{array}{l}\text { svako spominjanje: Darko Horvat, ministar, ministarstvo - važni članci, } \\
\text { puni sadržaj; }\end{array}$ \\
\hline Ministarstvo kulture i medija & $\begin{array}{l}\text { svako spominjanje: Nina Obuljen Koržinek, ministrica, ministarstvo - } \\
\text { važni članci, puni sadržaj; }\end{array}$ \\
\hline Ministarstvo obrane & $\begin{array}{l}\text { svako spominjanje: Mario Banožić ministar, ministarstvo - važni članci, } \\
\text { puni sadržaj; }\end{array}$ \\
\hline Ministarstvo poljoprivrede & $\begin{array}{l}\text { svako spominjanje: Marija Vučković, ministrica, ministarstvo - važni } \\
\text { članci, puni sadržaj; }\end{array}$ \\
\hline $\begin{array}{l}\text { Ministarstvo mora, prometa i } \\
\text { infrastrukture }\end{array}$ & $\begin{array}{l}\text { svako spominjanje: Oleg Butković, ministar, ministarstvo - važni } \\
\text { članci, puni sadržaj; }\end{array}$ \\
\hline Ministarstvo pravosuđa i uprave & $\begin{array}{l}\text { svako spominjanje: Ivan Malenica, ministar, ministarstvo - važni članci, } \\
\text { puni sadržaj; }\end{array}$ \\
\hline $\begin{array}{l}\text { Ministarstvo rada, mirovinskoga } \\
\text { sustava, obitelji i socijalne politike }\end{array}$ & $\begin{array}{l}\text { svako spominjanje: Josip Aladrović, ministar, ministarstvo - važni } \\
\text { članci, puni sadržaj; }\end{array}$ \\
\hline $\begin{array}{l}\text { Ministarstvo regionalnoga razvoja i } \\
\text { fondova Europske unije }\end{array}$ & $\begin{array}{l}\text { svako spominjanje: Nataša Tramišak, ministrica, ministarstvo - važni } \\
\text { članci, puni sadržaj; }\end{array}$ \\
\hline Ministarstvo turizma i sporta & $\begin{array}{l}\text { svako spominjanje: Nikolina Brnjac, ministrica, ministarstvo - važni } \\
\text { članci, puni sadržaj; }\end{array}$ \\
\hline Ministarstvo unutarnjih poslova & $\begin{array}{l}\text { svako spominjanje: Davor Božinović, ministar, ministarstvo - važni } \\
\text { članci, puni sadržaj; }\end{array}$ \\
\hline $\begin{array}{l}\text { Ministarstvo vanjskih i europskih } \\
\text { poslova }\end{array}$ & $\begin{array}{l}\text { svako spominjanje: Gordan Grlić Radman, ministar, ministarstvo - } \\
\text { važni članci, puni sadržaj; }\end{array}$ \\
\hline Ministarstvo zdravstva & $\begin{array}{l}\text { svako spominjanje: Vili Beroš, ministar, ministarstvo - važni članci, } \\
\text { puni sadržaj; }\end{array}$ \\
\hline Ministarstvo znanosti i obrazovanja & $\begin{array}{l}\text { svako spominjanje: Radovan Fuchs, ministar, ministarstvo - važni } \\
\text { članci, puni sadržaj; }\end{array}$ \\
\hline
\end{tabular}

Tablica 1. Popis tema koje su kriterij izbora u uzorak N2

\section{Obuhvat tiskovina (print medija) za uzorak istraživanja:}

Pretragom su obuhvaćeni sve novine, magazini, časopisi i druga tiskana izdanja Republike Hrvatske čiji je datum izdanja između 1.1.2021. i 2.3.2021. Ukupan broj različitih tiskovina u promatranom periodu je $(\mathbf{N} 3=\mathbf{3 3 0})$, što uključuje različita izdanja i podlistke tiskovina. U uzorku je $(\mathbf{N} 4=\mathbf{1 1 5})$ različitih tiskovina. Spajanjem različitih izdanja tiskovina, broj tiskovina u uzorku je (N5=95). Broj od 95 različitih tiskovina u uzorku računat je na način da se različita izdanja jedne tiskovine broje kao jedan, umjesto da se svako izdanje broji zasebno. Tako na primjer Večernji list, koji ima večernje i regionalna izdanja se broji kao jedan a ne kao nekoliko zasebnih tiskovina; i takav način brojenja daje ukupno 95 različitih tiskovina u uzorku.

Da pojasnimo razliku između 330 tiskovina ukupne populacije i 115 tiskanih izdanja u uzorku. U 215 tiskovina se ne spominje niti jedan pojam (Vlada, premijer, ministri i ministarstva) te iz tih razloga nisu uvršteni $\mathrm{u}$ analizu. Ovaj podatak je također sam po sebi indikativan. Radi se o tiskovinama tipa More, Cosmopolitan, Bug i sl.

Ukupan broj pregledanih tiskovnih članaka u danom periodu iznosi 71295 članaka, od kojih je izdvojeno 6379 članaka u uzorak. Drugim riječima, od ukupno 71295 tiskanih članaka u promatranom periodu, 6379 članka, ili 8,95\%, se odnosi na predmet našeg istraživanja. 
Udio članaka izdvojenih u uzorak u odnosu na ukupan broj članaka u promatranom razdoblju

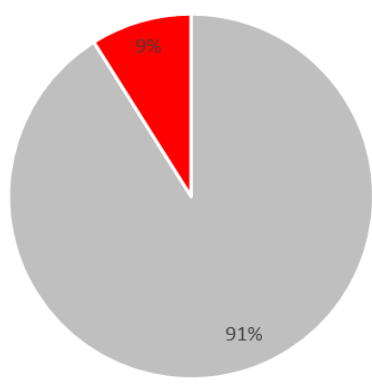

\section{Grafikon 1. Odnos uzorka i populacije}

\section{Kategorije analize}

Jedinica analize sadržaja je jedan novinski članak. U analizu nisu uključeni plaćeni članci (plaćene PR objave i oglasi).

Analizom je obuhvaćeno 15 kategorija analize sadržaja, sa pripadajućim česticama. Ključne kategorije analize su: medij odnosno tiskovina u kojoj je članak objavljen, tematika, učestalost izlaženja tiskovine, pokrivenost tiskovine, tematika tiskovine, rubrika iz tiskovine kojoj članak pripada, datum izdanja, naslov članka, podnaslov članka, tekstualni sadržaj članka, površina članka mjerena centimetrima kvadratnim, vrijednost članka, Opportunity to see (OTS), veličina članka mjerena brojem znakova.

Učestalost izlaženja pojedine tiskovine može biti: dnevna, tjedna, mjesečna, dvotjedna, dvomjesečna, kvartalna, polugodišnja, godišnja i povremena.

Pokrivenost tiskovine može biti nacionalna, regionalna, lokalna ili interno glasilo.

Tematika tiskovine odnosi se na opis sadržaja koji se objavljuje $u$ pojedinoj tiskovini. $U$ uzorku su zastupljene tiskovine sljedećih tematika: Informativno politički list, List za muškarce, Stručni list, List za žene, List za kulturu, Informatički list, Sportski list, Vjerski list, Gospodarski list, Zabavni list; Glazba, moda, film; Omladinski list, Obiteljski list.

Vrijednost članka je izveden podatak koji se sastoji od tržišne vrijednosti oglasnog prostora pojedinih novina i površine članka. Stvarna vrijednosti bi se mogla mijenjati i biti umanjena s obzirom na eventualne posebne pogodnosti koje pojedini kupac ugovori sa pojedinom tiskovinom, stoga je za prikaz vrijednosti $u$ obzir uzeta standarda vrijednost prema cjeniku. Opportunity to see (OTS) predstavlja podatak o mogućem broju čitatelja koji su vidjeli članak i dobiven je temeljem provedenog istraživanja čitanosti na nacionalno reprezentativnom uzorku.

Metodološki gledano, u obzir treba uzeti i činjenicu da je prilikom pretvorbe digitalizirane slike stranice tiskovine $\mathrm{u}$ tekst korištena tehnologija OCRa (optical caracter recognizer) koja ima prosječnu grešku od $2 \%$ pogrešno „pročitanih“ slova sa slike članka što je u ovom slučaju najveća moguća greška uzorka.

Smatramo potrebnim istaknuti da su u pretrazi baze podataka korišteni NLP/natural language procesing/ tehnologije, klasifikator s naprednim logičkim operatorima i statističkim modelom pojavnosti riječi $u$ tekstu, NERC /named entity recognition/, Event detection i ostale jezične tehnologije. Zadana veličina ovog rada ne dozvoljava istraživačima prezentiranje rezultata obrade korpusa NLP tehnologijama unutar ovog rada. Ostavljamo tu mogućnost za slijedeće longitudinalno istraživanje. HRVATSKIM TISKOVINAMA O VLADI RH 
Na grafikonu 2. je prikazana razdioba broja članaka prema datumu izdanja tiskovine. Prosječno je dnevno objavljivano 104,57 članaka o Vladi i Ministarstvima. Standardna devijacija prosječnog dnevnog broja članaka iznosi 44,97, a koeficijent varijacije 39,74\% što ukazuje na slabu varijabilnost broja članaka po danima. Pod pretpostavkom normalne distribucije broja članaka po danu, očekivana dnevna količina članaka u tiskovinama iznosi između 63 i 146 članaka. Najmanje članaka objavljeno je 28.2.2021. - 29 članaka, a najviše 26.2.2021. - 197 članaka. Medijan broja objava iznosi 103 članaka dnevno.

\section{Ukupan broj članaka po datumu izdanja}

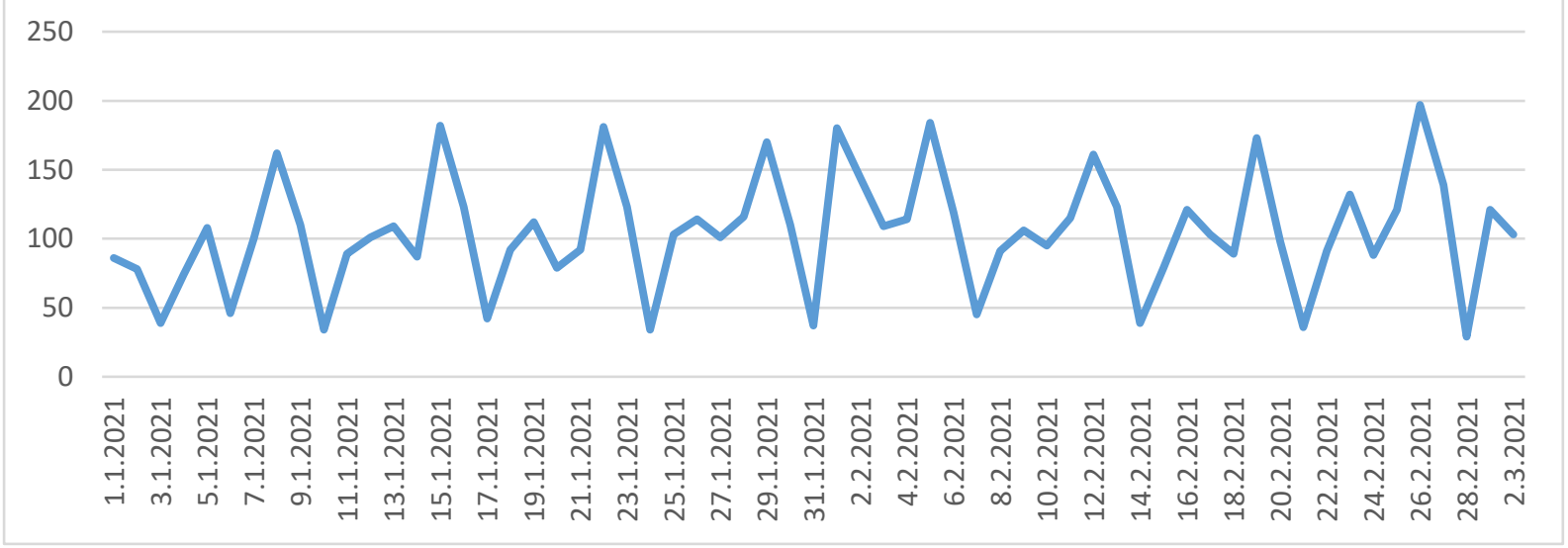

\section{Grafikon 2. Brojnost članaka po datumu izdanja}

Distribucija broja objava prema temama prikazana je na grafikonu 3. Neki članci mogu istovremeno pripadati više od jednoj temi te je stoga suma broja članaka po temama veća od broja članaka u uzorku, što je i očekivano.
Prosječno je svaki članak pripadao u dvije teme (prosjek iznosi 1,6), što znači da članci $u$ prosjeku ne obrađuju samostalno samo jednu od tema ili ministarstva (premijera i drugo), već se pojavljuju u prosjeku dvoje zajedno.

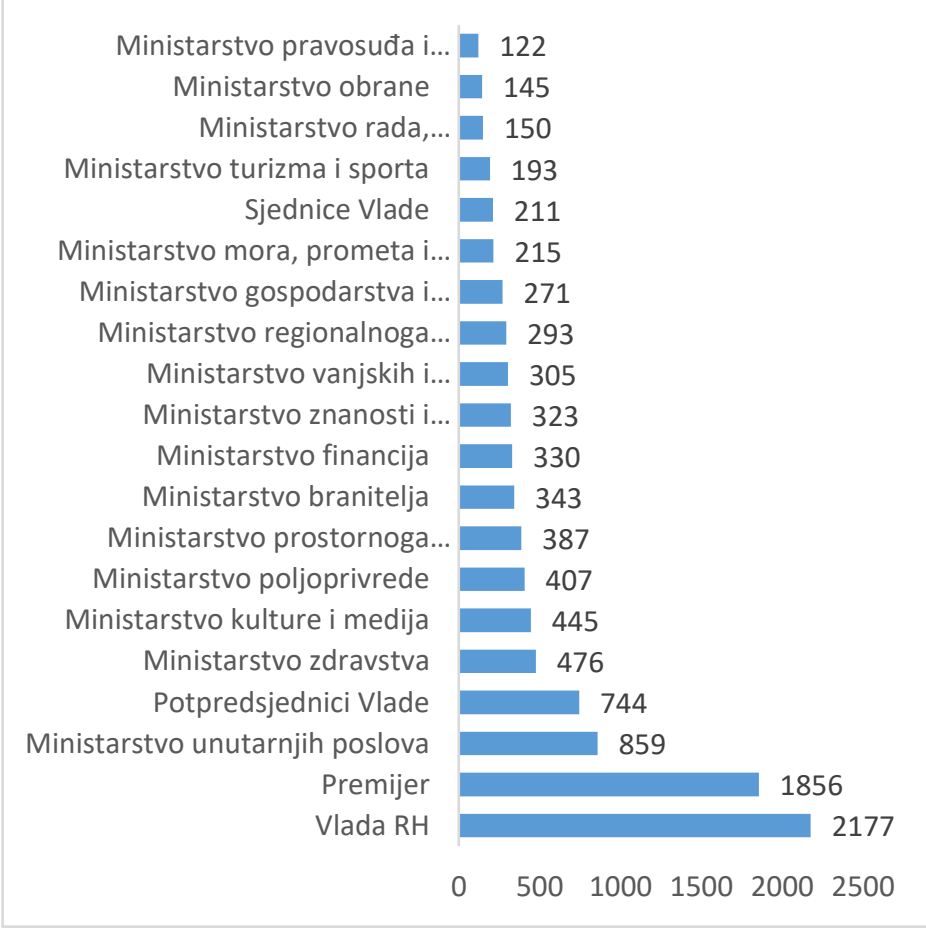

\section{Grafikon 3. Brojnost članaka po temi}




\begin{tabular}{|l|r|}
\hline Naziv teme & Broj članaka po temi \\
\hline Vlada RH & 2177 \\
\hline Premijer & 1856 \\
\hline Ministarstvo unutarnjih poslova & 859 \\
\hline Potpredsjednici Vlade & 744 \\
\hline Ministarstvo zdravstva & 476 \\
\hline Ministarstvo kulture i medija & 445 \\
\hline Ministarstvo poljoprivrede & 407 \\
\hline Ministarstvo prostornoga uređenja, graditeljstva i državne imovine & 387 \\
\hline Ministarstvo branitelja & 343 \\
\hline Ministarstvo financija & 330 \\
\hline Ministarstvo znanosti i obrazovanja & 323 \\
\hline Ministarstvo vanjskih i europskih poslova & 305 \\
\hline Ministarstvo regionalnoga razvoja i fondova Europske unije & 293 \\
\hline Ministarstvo gospodarstva i održivog razvoja & 271 \\
\hline Ministarstvo mora, prometa i infrastrukture & 215 \\
\hline Sjednice Vlade & 211 \\
\hline Ministarstvo turizma i sporta & 193 \\
\hline Ministarstvo rada, mirovinskoga sustava, obitelji i socijalne politike & 150 \\
\hline Ministarstvo obrane & 145 \\
\hline Ministarstvo pravosuđa i uprave & 122 \\
\hline
\end{tabular}

\section{Tablica 2. Brojnost članaka po temi}

Tablica 2. pokazuje kako je medijski interes usmjeren prema Vladi i premijeru. Od ukupno 6379 članaka iz uzorka, 2177 ili 34\% članaka tematiziraju Vladu. 1856 članaka ili 29\% objava iz uzorka tematiziraju premijera.

U tablici 3. je prikazano koliko članaka pripada koliko tema. $64,78 \%$ članaka (dakle većina) pripada samo $u$ jednu temu, što znači da se odnose samo na jedno ministarstvo ili samo na Vladu. Najveći broj tema u koje jedan članak pripada je 13 (od ukupno 20 tema). Pokazatelj raspodjele članaka po temama, odnosno učestalost pojavljivanja različitih tema unutar jednog članka, ukazuje na relativno slabu učestalost zajedničkog spominjanja više od jedne teme unutar članka, budući je 64,78\% članaka pripada samo jednoj temi.

\begin{tabular}{|l|l|l|}
\hline broj tema & broj članaka po temi & udio \\
\hline 1 & 4132 & $64,78 \%$ \\
\hline 2 & 1348 & $21,13 \%$ \\
\hline 3 & 541 & $8,48 \%$ \\
\hline 4 & 190 & $2,98 \%$ \\
\hline 5 & 97 & $1,52 \%$ \\
\hline 6 & 31 & $0,49 \%$ \\
\hline 7 & 15 & $0,24 \%$ \\
\hline 8 & 6 & $0,09 \%$ \\
\hline 9 & 4 & $0,06 \%$ \\
\hline 10 & 0 & $0,00 \%$ \\
\hline 11 & 3 & $0,05 \%$ \\
\hline 12 & 8 & $0,13 \%$ \\
\hline 13 & 4 & $0,06 \%$ \\
\hline
\end{tabular}


61

\section{Tablica 3. Tematska zastupljenost članaka}

Medijska pojavnost mjerena brojem članaka razlikuje se od tiskovine do tiskovine. 20 tiskovina koje su imale najviše članaka vezanih za promatrane teme su dane $u$ tablici 4 . Tih 20 tiskovina čine 21\% (od ukupno 95 tiskovina) i u njima je objavljeno $85 \%$ svih članaka iz uzorka. Svakako treba u obzir uzeti i činjenicu da su tiskovine sa najvećim brojem objava sve dnevne ili tjedne novine, te da po svojoj tematici (odnosno sadržaju o kojem pišu) spadaju u informativno političke listove. Samo dvije tiskovine sa liste top 20 tiskovina po broju članaka koje tematiziraju Vladu, premijera, ministarstva i ministre (itd.) nisu informativno političke tematike; Poslovni dnevnik i Lider spadaju u gospodarske listove.

\begin{tabular}{|c|l|c|c|}
\hline redni broj & \multicolumn{1}{|c|}{ Novine2 } & Broj članaka & $\begin{array}{c}\text { Kumulativni udio u } \\
\text { ukupnom broju članaka }\end{array}$ \\
\hline 1 & Večernji list & 850 & $13,32 \%$ \\
\hline 2 & Novi list & 633 & $23,25 \%$ \\
\hline 3 & Jutarnji list & 601 & $32,67 \%$ \\
\hline 4 & Zadarski list & 569 & $41,59 \%$ \\
\hline 5 & Slobodna Dalmacija & 511 & $49,60 \%$ \\
\hline 6 & Glas Slavonije & 504 & $57,50 \%$ \\
\hline 7 & 24 sata & 375 & $63,38 \%$ \\
\hline 8 & Glas Istre & 365 & $69,10 \%$ \\
\hline 9 & Nacional & 130 & $71,14 \%$ \\
\hline 10 & Poslovni dnevnik & 108 & $72,83 \%$ \\
\hline 11 & 7 Dnevno & 99 & $74,38 \%$ \\
\hline 12 & Hrvatski tjednik & 92 & $75,83 \%$ \\
\hline 13 & 7 Plus Regionalni tjednik & 84 & $77,14 \%$ \\
\hline 14 & Varaždinske vijesti & 83 & $78,44 \%$ \\
\hline 15 & 24express & 79 & $79,68 \%$ \\
\hline 16 & Novosti & 78 & $80,91 \%$ \\
\hline 17 & Lider & 74 & $82,07 \%$ \\
\hline 18 & Dubrovački vjesnik & 72 & $83,19 \%$ \\
\hline 19 & Glas Grada & Vinkovački list & $84,15 \%$ \\
\hline 20 & 20 medijskih izdania & & $89 \%$ \\
\hline
\end{tabular}

\section{Tablica 4. Top 20 medijskih izdanja po broju analiziranih članaka}

Pregled broja članaka obzirom na tematiku tiskovine i učestalost izlaženja dana je u tablici 5.

\begin{tabular}{|c|c|c|c|c|c|c|c|c|c|c|}
\hline \multirow[b]{2}{*}{ Tematika tiskovine } & \multicolumn{9}{|c|}{ Učestalost izlaženja tiskovina } & \multirow[b]{2}{*}{ Ukupno } \\
\hline & Dnevna & Tjedna & Dvotjedna & Mjesečna & Dvomjesečna & Kvartalna & Polugodišnja & Godišnja & Povremena & \\
\hline Informativno politički list & 4389 & 1336 & 127 & 67 & 3 & & & & 57 & 5979 \\
\hline Gospodarski list & 108 & 74 & & 1 & 4 & 7 & & & & 194 \\
\hline Sportski list & 15 & 1 & 2 & 10 & & & & & & 28 \\
\hline Glazba, moda, film & & 13 & & & & & & & & 13 \\
\hline Informatički list & & & & 8 & & & & & & 8 \\
\hline List za kulturu & & & 24 & & 1 & & & & & 25 \\
\hline List za muškarce & & & & 1 & & & & & & 1 \\
\hline List za žene & & 6 & & & & & & & & 6 \\
\hline Obiteljski list & & & & 10 & & 1 & & & & 11 \\
\hline Omladinski list & & & & 7 & & & & & & 7 \\
\hline Stručni list & & 15 & & 49 & 8 & & 1 & 5 & 16 & 94 \\
\hline Vjerski list & & & & 3 & 1 & & & & & 4 \\
\hline Zabavni list & & 5 & & 4 & & & & & & 9 \\
\hline Ukupno & 4512 & 1450 & 153 & 160 & 17 & 8 & 1 & 5 & 73 & 6379 \\
\hline
\end{tabular}




\section{Tablica 5. Brojnost članaka s obzirom na tematiku tiskovine i učestalost objave tiskovine}

Očekivano najviše članaka je objavljeno u tiskovinama informativno političke tematike ukupno 5979 ili 93,73\% članaka. Ukupno 60 ili udjelom 63\% svih tiskovina iz uzorka je informativno političke tematike. Gledajući prema učestalosti izlaženja, najviše članaka (93,46\% ili 5962 članaka) je objavljeno u dnevnim i tjednim tiskovinama. Ukupan broj različitih dnevnih tiskovina u uzorku je 11, tjednika 32 a mjesečnika 29.

U promatranom razdoblju prosječni broj objava vezanih uz Vladu i Ministarstva je 75,2 članka dnevno, što uz koeficijent varijacije od 30\% ukazuje na slabu varijabilnost broja članaka u dnevnim novinama.

Gledajući samo članke $u$ dnevnim novinama, dan je prikaz prosječnog dnevnog broja članaka $\mathrm{u}$ dnevnim novinama $\mathrm{s}$ obzirom na dan $\mathrm{u}$ tjednu. U prosjeku se najviše članaka o Vladi i Ministarstvima objavljuje subotom (prosječno 99,4 članaka), a značajno najmanje nedjeljom (prosječno 33,6 članaka) što je i očekivano.

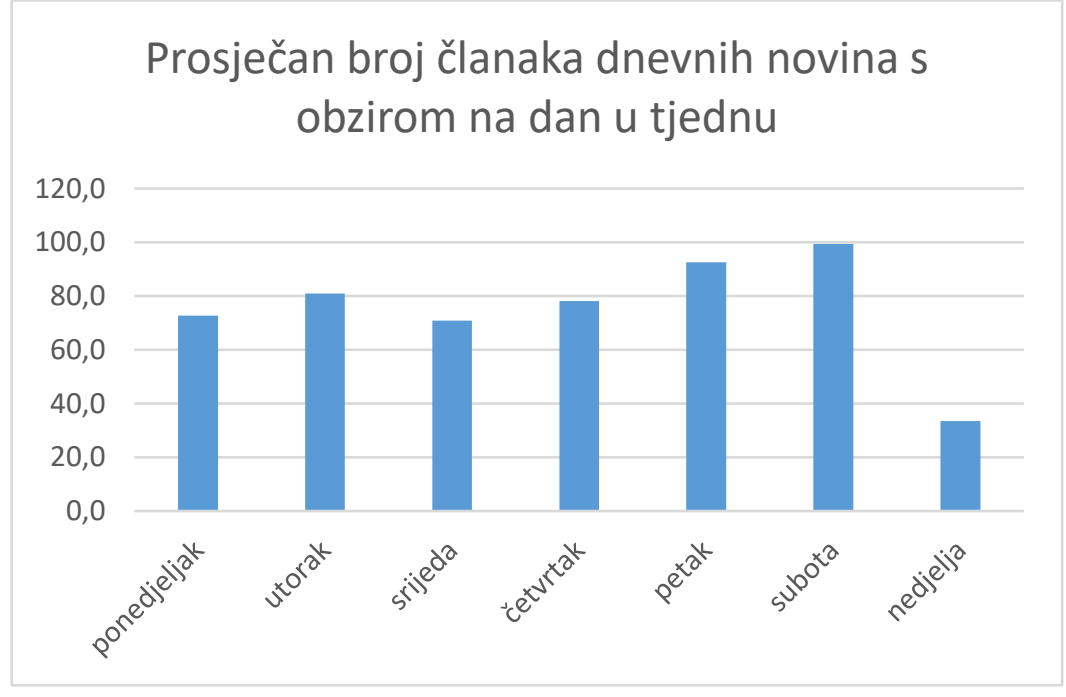

\section{Grafikon 4. Distribucija prosječne brojnosti članaka po danima u tjednu}

Prosječna veličina članaka mjerena brojem znakova teksta iznosi 4807,50 znakova. Medijan broja znakova po članku iznosi 3688, što znači da je pola članaka imalo 3688 znakova ili manje, a 50\% članaka je imalo 3688 znak ili više. Koeficijent varijacije broja znakova po članku je relativno velik i iznosi $91,66 \%$. Ovaj podatak ukazuje na postojanje vrlo malih i vrlo velikih članaka koji tematiziraju Vladu i ministarstva. Prosječna veličina članka iznosi 774,54 cm2. Medijalna veličina članaka je 562,44 cm2. Ukupna površina članaka koja se odnosila na predmetne teme iznosila je $4940807 \mathrm{~cm} 2$ (ili 494 metara kvadratnih). Standardna devijacija iznosi $753 \mathrm{~cm} 2$, a koeficijent varijacije $97,25 \%$, što je visoka razina varijabilnosti $u$ površini tiskovnih objava.

Ukupna vrijednosti tiskovnih objava iznosi 109849015 kn. Prosječna vrijednost objave iznosi 17293,61 kn. Koeficijent varijacije ukazuje na veliku varijabilnost vrijednosti tiskovnih objava i iznosi $152,88 \%$.

Koji su to autori odnosno novinari koji najčešće ili najviše pišu o temama koje su predmet interesa ovog istraživanja?

Na grafikonima 5., 6. i 7. dan je prikaz autora odnosno novinara članaka prema tri kriterija: autori koji su napisali najviše tiskovnih objava, autori čije su tiskovne objave najvrjednije $u$ protuvrijednosti u kunama, te autori čije objave imaju najveću površinu. 


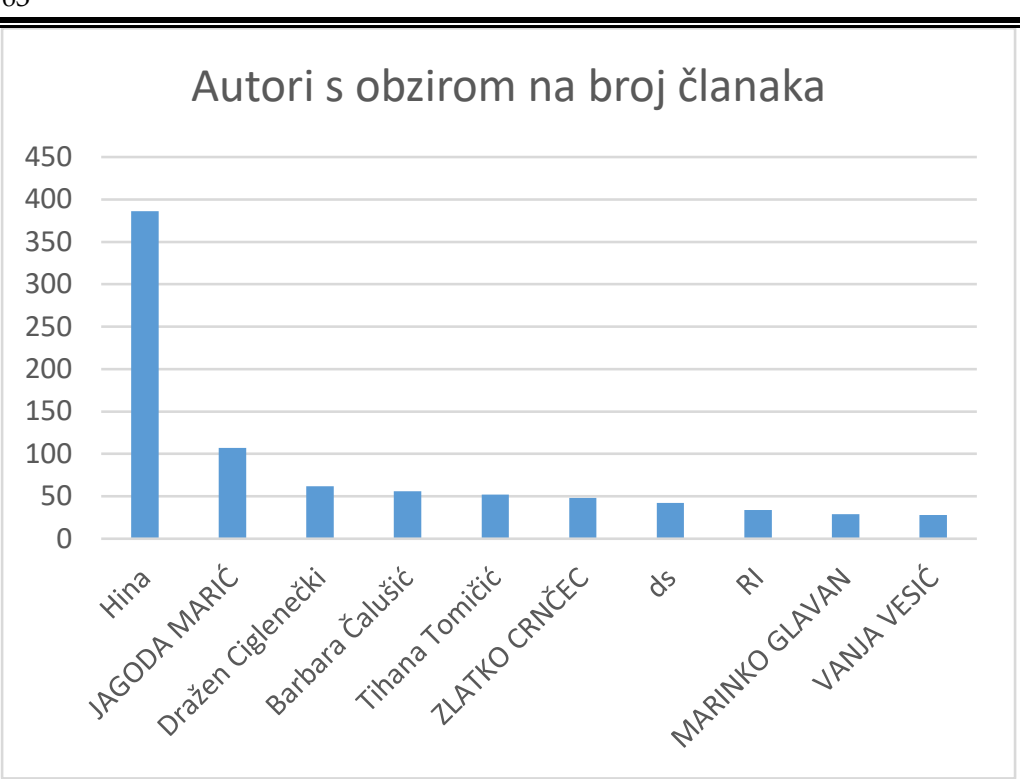

\section{Grafikon 5. Brojnost članaka po autoru}

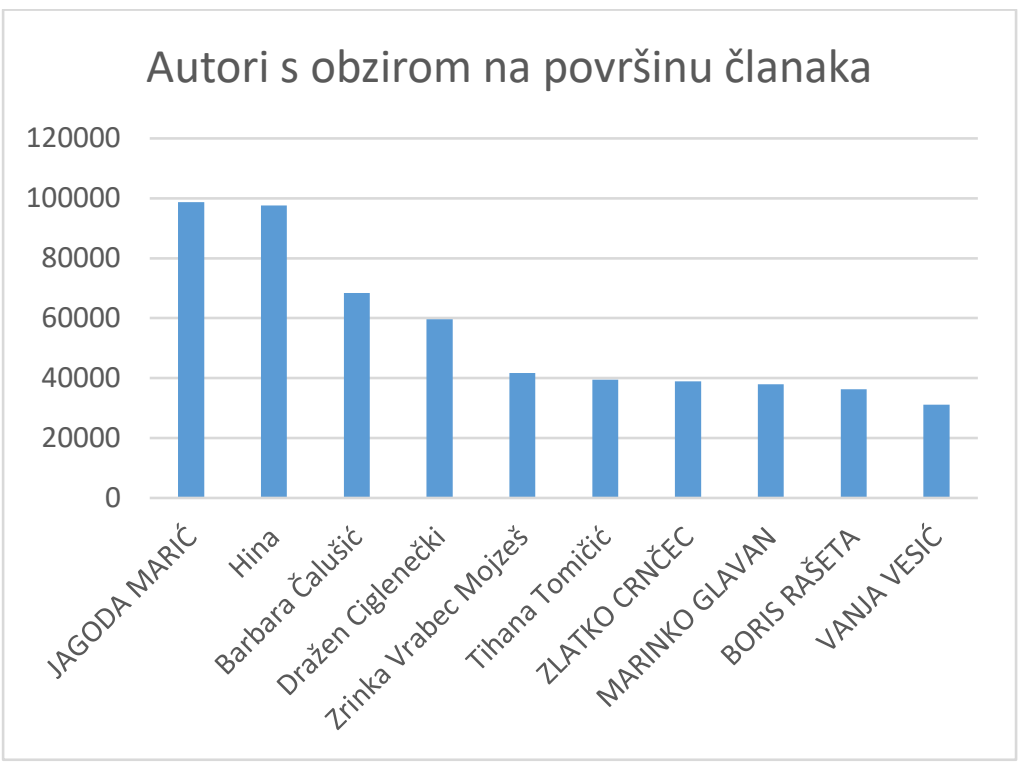

Grafikon 6. Površina članak po autoru 


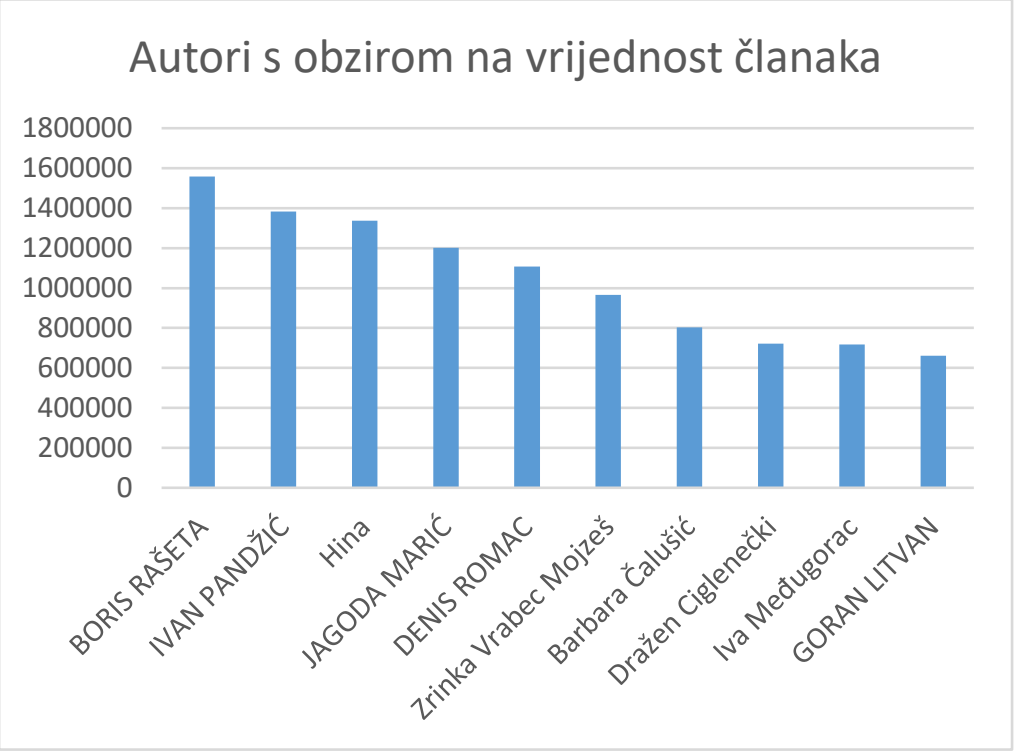

\section{Grafikon 7. Vrijednost članka po autoru}

Upotrebom NLP tehnologije NERC ekstrahirali smo pojavnost osoba i institucija iz uzorka. Ukupno je pronađeno 17046 različitih osoba koje se imenom ili prezimenom (ili oboje) pojavljuju u tekstu promatranih članaka. Neovisno o tome spominje li se osoba samo prezimenom ili punim imenom i prezimenom, prikazan je podatak spominjanja prema imenu i prezimenu pojedine osobe. Potrebno je naglasiti kako tehnologija ekstrahira samo imenovane entitete što znači da osoba ili institucija (entitet) moraju biti eksplicitno napisani unutar članka. Osobe ili institucije koje nisu eksplicitno napisani već čitatelj iz konteksta (ili slike) može razumjeti o kojoj osobi ili instituciji se piše, neće biti prepoznati i ekstrahirani te stoga nisu uključeni u ovaj prikaz.

Distribucija broja pojavljivanja entiteta: osobe je izrazito pozitivno asimetrična. Koeficijent asimetrije $\alpha_{3}$ iznosi velikih 78 . Ovaj podatak zapravo ne iznenađuje jer je i očekivano da će sadržaj promatranih članaka biti usmjeren na osobe koje su bile temelj za kreiranje uzorka. Drugi razlog zbog kojeg visoka asimetričnost podataka ne iznenađuje je širok djelokrug institucija (Vlade i ministarstava), te je za očekivati da će u sadržaju članaka biti spomenuto mnogo različitih osoba.

Broj pojavnosti entiteta mjeri se dvama brojevima. Prvi broj je broj članaka u kojima se pojedina osoba pojavljuje. a drugi broj je broj pojavnosti osobe. Pojavnost pojedine osobe je najmanje jednaka broju članaka u kojima se osoba pojavila. Ključna razlika između ova dva broja sastoji se $\mathrm{u}$ tome da brojnost članaka $\mathrm{u}$ kojima se osoba pojavljuje ne uzima u obzir koliko se puta spomenula neka osoba u članku i svejedno je spomene li se osoba jednom ili pedeset puta, prilikom brojanja članaka $u$ kojima se osoba pojavljuje broj će biti jedan.

U tablici 5. daje se prikaz najčešće spominjanih osoba s obzirom na broj članaka u kojima su spomenuti. Očekivano najčešće se spominje premijer Andrej Plenković. Andrej Plenković spominje se u 1790 članaka što iznosi $28 \%$ članaka iz uzorka. U uzorku je pronađeno 4718 puta ime Andreja Plenkovića što znači da je u prosjeku, u svakom članku $\mathrm{u}$ kojem je spomenut, Andrej Plenković je spomenut 2,63 puta.

Vili Beroš je treći na listi najpojavljivanijih osoba sa 348 članaka i 762 spominjanja, dok je Davor Božinović peti po redu s obzirom na broj članaka u kojima se spominje, dok je po ukupnom broju pojavljivanja na osmom mjestu. Drugi prikaz za kojeg je korištena NLP tehnologija NERC odnosi se na entitete: institucije. Potrebno je pojasniti kako tehnologija ekstrakcije entiteta pod institucijama podrazumijeva ministarstva i organizacije ali i županije, stranke i različite 
institucije poput društava, udruga, komora, zavoda itd.

Ukupan broj različitih organizacija ekstrahiranih iz promatranog uzorka je 13819.

Distribucija pojavnosti različitih organizacija je izrazito asimetrična. Koeficijent asimetrije $\alpha_{3}$ iznosi velikih 52 .

Vlada Republike Hrvatske pojavljuje se u najvećem broju članaka. Od ukupno 6379

\begin{tabular}{|l|c|c|c|c|}
\hline \multicolumn{1}{|c|}{ Naziv organizacije } & $\begin{array}{c}\text { Broj članaka u } \\
\text { kojima se } \\
\text { organizacija } \\
\text { pojavljuje }\end{array}$ & $\begin{array}{c}\text { Broj } \\
\text { pojavljivanja } \\
\text { organizacije }\end{array}$ & $\begin{array}{c}\text { Redni broj } \\
\text { pojavljivanja } \\
\text { organizacije }\end{array}$ & $\begin{array}{c}\text { Udio pojavnosti } \\
\text { u ukupnom } \\
\text { broju članaka }\end{array}$ \\
\hline Vlada Republike Hrvatske & 2721 & 5562 & 2 & $42,66 \%$ \\
\hline Europska Unija & 2398 & 5084 & 3 & $37,59 \%$ \\
\hline HDZ & 1359 & 5640 & 1 & $21,30 \%$ \\
\hline Hrvatski sabor & 928 & 1745 & 5 & $14,55 \%$ \\
\hline
\end{tabular}

Tablica 6. Pojavnosti organizacija unutar promatranog uzorka

Daljnja analiza pojavnosti entiteta uključivala bi komparaciju zajedničkog pojavljivanja unutar članaka umjesto skupno na razini uzorka, pridjeljivanje sentimenta spram pojedinih osoba i institucija te detekciju događaja i grupiranje pojavnosti entiteta unutar pojedinih događaja.

\section{KVANTITATIVNA I KVALITATIVNA ANALIZA ČLANAKA}

Obzirom na veliku količinu tiskovnih objava koje su u periodu od 1.1. do 2.3. 2021. tematizirale Vladu, premijera, Ministre i ministarstva, kvalitativna analiza sadržaja napravljena je na suženom uzorku.

6379 članka predstavlja populaciju, popis svih tiskovnih objava koje $\mathrm{u}$ promatranom periodu tematiziraju Vladu (i ostale teme). Od tih 6379 tiskovnih objava kvalitativno je obrađeno 296 tiskovnih objava.

Primarni cilj kvalitativne analize sadržaja tiskovnih objava je bio ustanoviti objektivnost i tonalitet sadržaja medijskih objava. Stoga je glavno pitanje analitičke matrice bilo definirati tonalitet pojedine objave spram Vlade RH. Varijabla tonaliteta spram Vlade RH poprima vrijednosti ordinalne skale od 5 razreda: ekstremno pozitivan članak, umjereno članaka iz uzorka, Vlada Republike Hrvatske pojavila se u $42,6 \%$ članaka. Po broju spominjanja unutar članaka najčešće se pojavljuje stranka HDZ (Hrvatska demokratska zajednica). Pronađeno je da se HDZ spominje 5640 puta. Vlada RH je po broju pojavljivanja u tekstu druga po redu, i pojavljuje se 5562 puta. pozitivan članak, neutralan članak, umjereno negativan članak i ekstremno negativan članak. Uzorkovanje je provedeno s obzirom na tri ključna parametra: U prvom koraku su izdvojeni samo oni tiskovni članci koji su tematizirali Vladu RH. Tih članaka je 6379. U sljedećem koraku su, slijedom realne vremenske dinamike objavljivanja tiskovnih medijskih sadržaja, odabrane pojedine tiskovine u uzorak. Prilikom izbora tiskovina $\mathrm{u}$ uzorak vodilo se računa o: učestalosti izlaženja pojedine tiskovine, pokrivenosti, i generalnoj naklonjenosti tiskovina pojedinim političkim opcijama. Ukupan broj različitih tiskovina $u$ uzorku iznosi 40 različitih tiskovina. U zadnjem koraku se metodom slučajnog izbora izabrani pojedini članci u uzorak, s tim da je dodatni kriterij bila veličina članaka mjerena brojem riječi - članci veličine manje od 500 znakova nisu uzimani u uzorak.

\section{EMPIRIJSKI REZULTATI}

$\mathrm{Na}$ grafikonu 8 prikazana je raspodjela pozitivnih, negativnih i neutralnih tiskovnih objava spram Vlade RH. Udio negativnih objava iznosi $23,55 \%$, pozitivnih ima 35,54\% a neutralnih $40,91 \%$ 


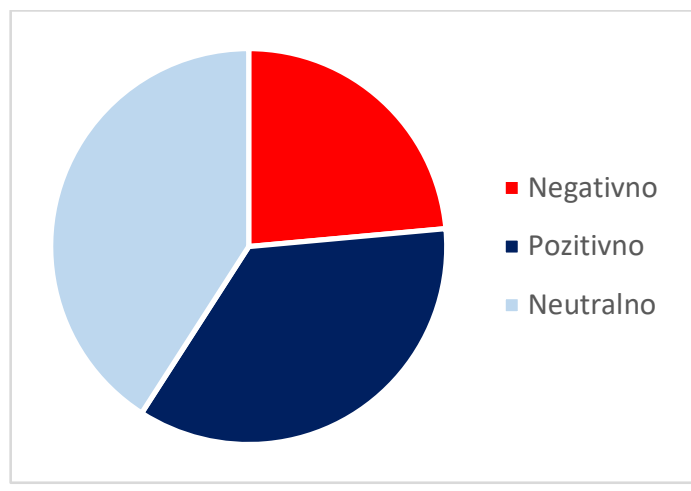

\section{Grafikon 8 Omjer sentimenta tiskovine spram Vlade RH}

Distribucija pozitivnih, negativnih i neutralnih objava dana je na grafikonu 9. Vidljivo je kako distribucija nije ravnomjerna već se udjeli pozitivnih, neutralnih i negativnih objava od tiskovine do tiskovine značajno razlikuju.

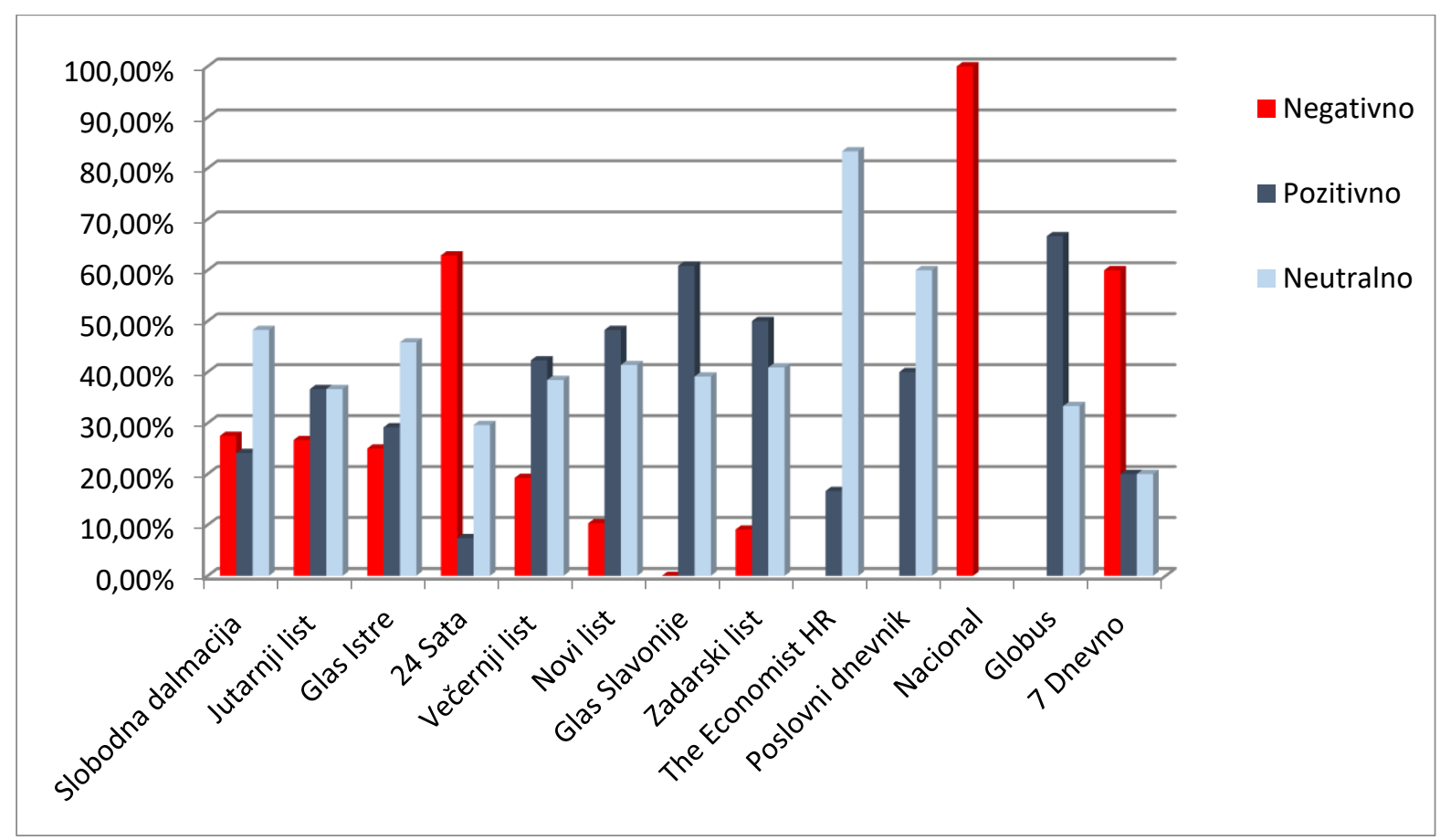

\section{Grafikon 9 Distribucija sentimente tiskovine spram Vlade RH po pojedinom mediju}

Obzirom na udio negativnih objava, predvodi

Nacional sa $100 \%$ negativnih objava u promatranom razdoblju kojeg slijedi 24 sata sa $62,9 \%$ negativnih objava. Promatrajući apsolute brojeve umjesto udjela, najviše negativnih objava objavljeno je u 24 sata (17), nakon čega slijede Jutarnji list i Slobodna Dalmacija, svaka sa 8 negativnih objava. Najveći udio pozitivnih objava je u Globusu $(100 \%)$, za kojim slijedi Glas Slavonije sa $60,86 \%$ pozitivnih objava. Najveći broj pozitivnih objava izražen apsolutnim brojem a ne udjelom, imaju Glas Slavonije i Novi list (14 objava svaki), za kojim slijede Jutarnji list, Večernji list i Zadarski list sa 11 objava.

Neutralne objave najzastupljenije su $\mathrm{u}$ godišnjaku The Economist HR (83\% objava), a drugi na toj listi je Poslovni dnevnik sa $60 \%$ neutralnih objava. Najveći broj neutralnih objava objavljeno je u Slobodnoj Dalmaciji (14 objava) a drugi po redu je Novi list sa 12 neutralnih objava. 
Promatrajući cjelokupni analizirani uzorak, ovo su mediji koji imaju najveći udio ekstremno negativnih i najveći udio pozitivnih medijskih objava spram Vlade RH u promatranom razdoblju (grafikoni 10. i 11.).

\section{Ekstremno negativni medijski sadržaj}

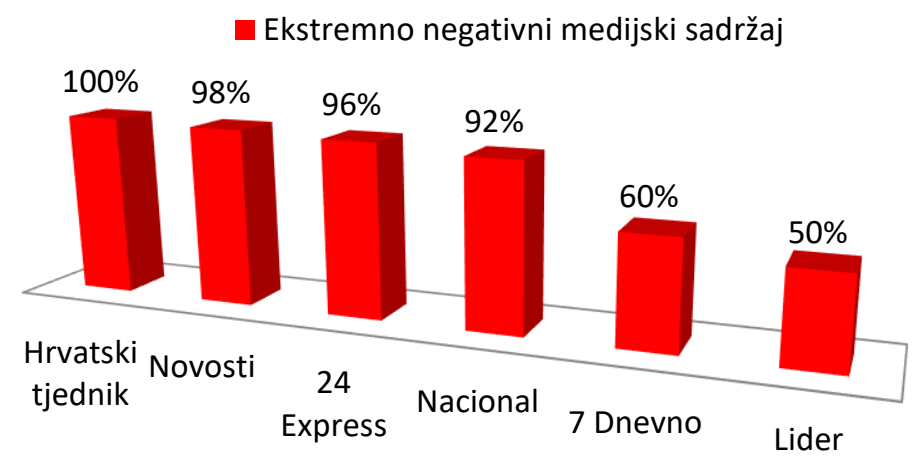

\section{Grafikon 10. Top 6 najnegativnijih tiskovina}

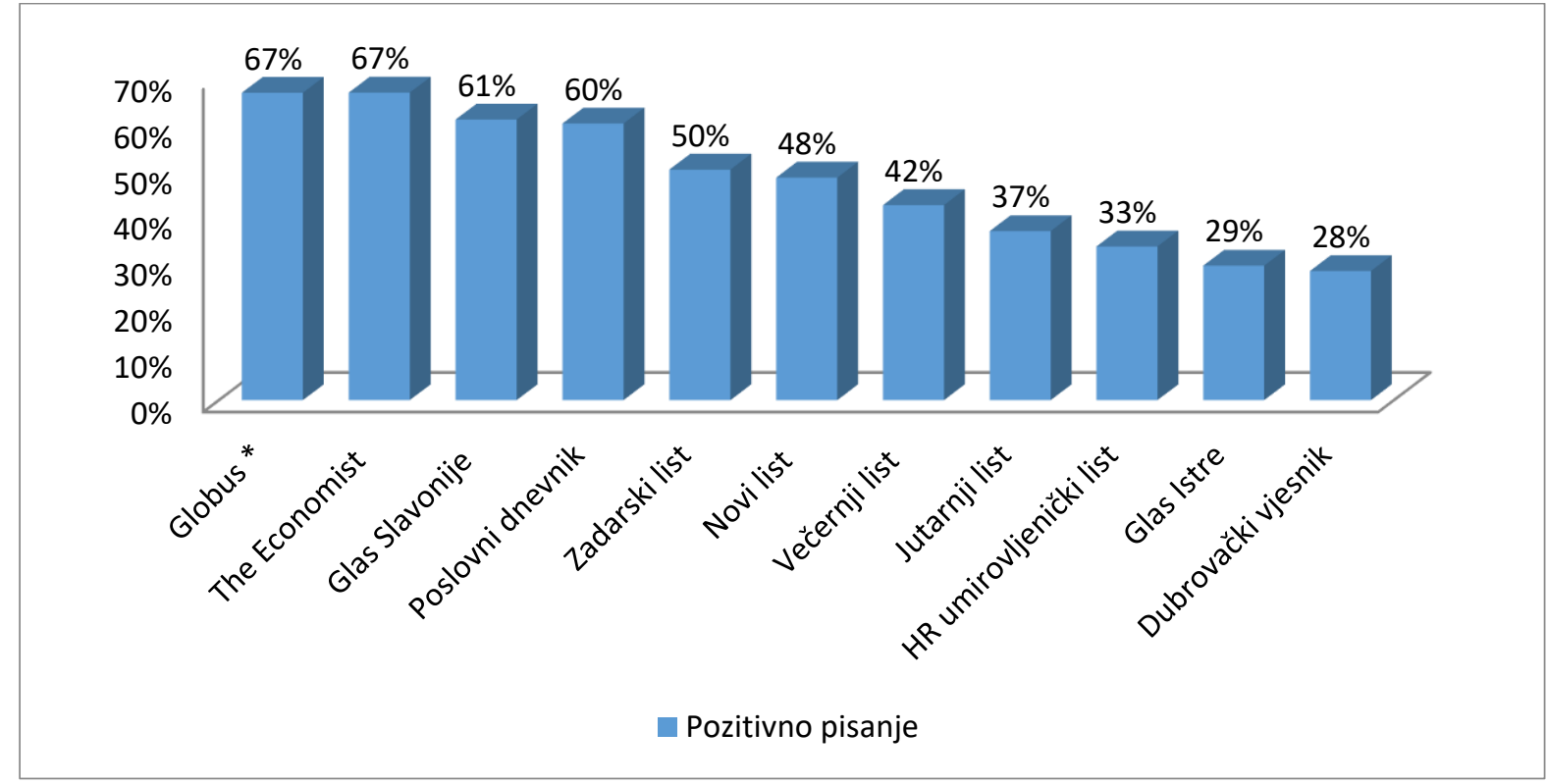

\section{Grafikon 11. Top 11 naj pozitivnijih tiskovina}

\section{ZAKLJUČAK}

Komunikološkim postupkom interpretacijske analize hrvatskih tiskovina (print-medijskih sadržaja) o Vladi RH došli smo da zanimljivih novih komunikoloških spoznajnih istraživačkih rezultata.

Pri koncipiranju ovog zahtjevnog istraživačkog projekta, bili smo svjesni, da smo, kao istraživači, ograničeni u svojim komunikološkim dometima i znanstvenim rizicima, s aspekta objektivne procjene i interpretacije stavova i mišljenja u hrvatskim tiskovinama o Vladi RH.

Empirijska istraživanja su uvijek opterećena velikim brojem stereotipa i političkih zabluda, koje proizlaze iz osobne iskustvene prošlosti autora (novinara i komunikatora) u hrvatskim tiskovinama koji se odnose na programski rad, aktivnosti, ugled i funkciju Vlade RH. Naime, u svakom čovjeku (novinaru / komunikatoru / istraživaču) postoji stečeno povijesno iskustvo koje stvara osobnu medijsku percepcijsku sliku 
o radu Vlade RH i državnih institucija. Unatoč tim činjenicama, smatrali smo da, nakon provedenog istraživanja, ovu komunikološko zanimljivu istraživačku problematiku nastavimo longitudinalno i sustavno empirijski istraživati u cilju detektiranja (ne)pristranih stavova i mišljenja $\mathrm{u}$ hrvatskim tiskovinama (pozitivni, neutralni ili negativni) o radu državnih institucija, na svim razinama upravljanja i vođenja državne politike. Nijedna ljudska tvrdnja nikada nije apsolutna i sigurna spoznaja pa tako ni analiza i evaluacija novinskih pisanih i vizualnih sadržaja. Iz tih razloga smo, $\mathrm{s}$ puno komunikoloških respektabilnih opreza, proveli holističku evaluaciju hrvatskih novinskih sadržaja na dinamičkom stohastičkom uzorku od 40 hrvatskih tiskovina u kojima je analiziran i evaluiran novinski pisani i vizualni sadržaji na uzorku od 296 novinskih medijskih sadržaja. Provedena je komunikološko evaluacijska i interpretacijska istraživačko analitička studija na tri komunikativne razine istraživanja, $i$ to: (1) Analitički pregled medijskih sadržaja na uzorku od N1= 71295 pisanih i vizualnih novinskih sadržaja, (2) Metodom genetsko strukturalne i statističke analize selektivno i analitički je evaluiran referentni uzorak (N2=6379) novinskih pisanih i vizualnih sadržaja i (3) Metodom prakseološke sadržajne dubinske statističke i evaluacijske metode izvršena je evaluacija novinskih sadržajna na uzorku od ( N3=296) pisana i vizualna novinska medijska sadržaja kroz pet standardnih komunikativnih razina komuniciranja: 1.objektivnost, 2. primjerenost, 3. brzina (pravovremenost) 4. atraktivnost i 5. društvena i komunikološko vektorsko usmjerena autorska sadržajno angažirana i orijentacijski usmjerena medijska slika u javnostima o programu, radu, aktivnostima i ugledu i funkciji Vlade RH. Istraživačka evaluacija je izvršena u vremenskim granicama od 2.siječnja do 2.veljače 2021. godine.

Dobiveni istraživački rezultati su pokazali da ukupna hrvatska novinska produkcija publicira 23,55 \% negativnih i pristranih medijskih sadržaja o Vladi RH. Dubinskom sadržajnom analizom istraživanje je pokazalo da u negativnim novinskim pisanim i vizualni sadržajima nedostaje ozbiljne logičke argumentacije, većinom su nevjerodostojni, (ne)kritički, senzacionalistički, populistički, zakulisnih i mističnih izvora informacija, opterećeni vlasničkim, stranačkim, gospodarskim i marketinškim interesnim utjecajnim te destabilizacijskim društvenim i stranačkim skupinama $\mathrm{u}$ hrvatskom javnom komuniciranju. Analiza negativnih novinskih sadržaja je pokazala izrazito slabo i površno poznavanje stručne tematsko sadržajne problematike. Politička, ekonomska i društvena sadržajna stajališta su više ili manje (pro)aktivistička, ponekad i anarhično destruktivna $u$ cilju destabilizacije programa, rada, aktivnosti, ugleda i funkcije Vlade RH. Dobivene istraživačke spoznaje su potvrdile osnovnu postavljenu istraživačku hipotezu (H1) koja problemski postavlja pitanje jesu li novinski sadržaji u hrvatskim tiskovinama pristrani te kako $\mathrm{u}$ novinskim sadržajima prikazuju iskrivljenu i preoblikovanu objektivnu stvarnost o Vladi RH u vremenima kriznog upravljanja i vođenja države. U negativnim medijskim sadržajima o Vladi RH prednjače tiskovine: Hrvatski tjednik, Novosti, 24 Express, Nacional, 7 Dnevno, Lider, Slobodna Dalmacija, Jutarnji list, Glas Istre, Večernji list i Glas Podravine. Možemo zaključiti da negativno pristrani novinski sadržaji (23,55\%), o radu i ugledu Vlade RH, u korelaciji s stvarnom nakladom hrvatskih tiskovina, svojim komunikacijskim utjecajnim dometom, su ispod $1 \%$ populacije građana Hrvatske, od ukupnog broja od 4.105.267 građana Hrvatske /19/. Temeljem dobivenih istraživačkih rezultata možemo zaključiti da negativni novinski pisani i vizualni sadržaji u hrvatskim tiskovinama nemaju signifikantnu moć utjecaja na građansko javno mnijenje o Vladi RH. Istina je da negativni novinski sadržaji, uz potporu političke oporbe, političkih aktivista iz grupacije civilnog društva, nevladinih organizacija i novinarskih udruga, mogu kolateralno utjecati na nacionalni i međunarodni referentni ugled Vlade RH na svim razinama globalne, regionalne, nacionalne i lokalne pozitivne medijske, političke i gospodarske javne komunikacije. Komunikološka interpretacija 
hrvatskih novinskih sadržaja, s jedne strane, ukazuje i na potencijalnu referentnu (ne)moć autora (novinara / komunikatora) koji mogu, s druge strane, frekventnim negativnim prikrivenim medijskim sadržajima stvarati negativni ugled o Vladi RH u domaćim i inozemnim javnostima. Analiza je pokazala da su hrvatski novinski mediji sami po sebi dobri, no, istraživanje je pokazalo da uredničku politiku vode male autorske skupine, koje negativnim strateškim medijskim sadržajima, uz aktivno simultano djelovanje na društvenim mrežama i kabelskim medijskim televizijskim portalima (posebno na kabelskom kanalu N1 s izrazito niskim postotkom gledanosti od 1,04 \% (Adsccanner top lista najgledanijih televizijskih kanala od 16.02.2021. godine od svih zemaljskih i nezemaljskih televizijskih kanala) mogu u javnosti stvarati percepcijski negativni dojam o radu i ugledu Vlade $\mathrm{RH}$ u javnostima /20/ To je komunikativni medijski sindrom "iz medija u medije" i na taj način medijski sadržaji postaju prikrivena utjecajna "medijska javnost". Istraživanje je također pokazalo da $35,54 \%$ print-medijskih sadržaja, koji su publicirani $u$ print-medijima: Globus, The Economist Croatia, Glas Slavonije, Poslovni dnevnik, Zadarski list, Novi list, Večernji list, Jutarnji list, HR umirovljenički list, Glas Istre su pozitivno orijentirani na rad ugled Vlade $\mathrm{RH} \mathrm{u}$ aktualnim kriznim vremenima upravljanja i vođenja države (pandemija COVID -19, razorni potresi u Zagrebu i Petrinji, nabavka cjepiva, društvene, gospodarske, političke i pluralističke različitosti, ulazak u Schengen i Euro zonu, kupnja aviona, strategija razvoja Hrvatske, demografija, lockdown, ekonomska i moguća turistička kriza, digitalizacija,...). Empirijsko istraživanje je također pokazalo da 40,91 \% medijskih sadržaja u hrvatskim tiskovinama je neutralno i objektivno u odnosu na program, rad, aktivnosti, ugled i funkciju Vlade RH na svim razinama političke, društvene i medijske komunikacije. Možemo ustvrditi da je provedena komunikološka interpretacija hrvatskih print-medijskih sadržaja potvrdila dodatnih 8 hipotetskih pretpostavki (H-1, H-2, H-3, H-4, H-5, H-6, H-7, H-8 i H-9), koje se odnose na; (H-2) stavove i mišljenje građana o medijskim sadržajima, $u$ hrvatskim tiskovinama (H-3) na objektivnost u prenošenju sadržajnih poruka, $(\mathrm{H}-4)$ na novinske sadržajne poruke o ugledu Vlade RH, (H-5) na brzinu / pravovremenost izvještavanja o sadržajima Vlade RH koji su od vitalnog značaja za život, rad i stvaralaštvo građana Hrvatske, (H-6) o atraktivnostima, odlukama, mjerama i reformama Vlade $\mathrm{RH},(\mathrm{H}-7) \mathrm{u}$ istraživanju medijskih sadržaja $u$ hrvatskim tiskovinama su prepoznate interpretacijske građanske vrijednosne, vlasničke, interesne i stranačke angažirane relacije $\mathrm{u}$ odnosu na Vladu RH. (H-8) Statistička obrada frekventnosti medijske pojavnosti Vlade Republike Hrvatske u cjelokupnom prostoru hrvatskih tiskovina postavlja osnovu za komparaciju i korelaciju kroz nastavak longitudinalnog istraživanja i (H-9) Najfrekventnije pojavljivanje osobe odnosi se na premijera Andreja Plenkovića što ukazuje na pridavanje velikog medijskog značaja premijeru. Istraživanje je također pokazalo kako je premijer Andrej Plenković medijski daleko najisturenija osoba budući se njegovo ime nalazi $u$ najvećem udjelu promatranih članaka iz uzorka (H-8).

Istraživanje je pokazalo, izvan naših očekivanja i postavljenih hipotetskih pretpostavki, pojavu ekstremno iracionalno negativistički printmedijskih sadržaja koji nisu u skladu s zakonitostima logičke argumentacije i strukturalnih zakonitosti print-medijskih izražajnih etičkih novinarskih i komunikoloških standarda o programu, radu, aktivnostima i ugledu Vlade RH. Printmedijska retorika, uz uvažavanje izražajnih specifičnosti, u javnim print-medijima: Hrvatski tjednik, Novosti, 24 Expres, Nacional, 7 Dnevno i Lider, s aspekta izražajne medijske retorike, obrade i eksplikacije informacije ne vode boljitku i razvoju građana Hrvatske.

Možemo zaključiti da medijski sadržaji, posebno novinski pisani i vizualni medijski sadržaji, u odnosu na rad Vlade $\mathrm{RH}$, nikada nisu predvidljivi kao ure (satovi) već su stohastičko nepredvidljivi. 
Bilješke

/1/ Nacionalna razvojna strategija-2030, u: Informatol. 53, 2020., 3-4, str.233 - 244.

/2/ Hrvatsko predsjedanje Vijećem Evropske unije, EU2020-HR, Vlada RH, Zagreb (2020) str. 1 - 48

/3/ Plenković A. (2020), u: Hrvatsko predsjedanje Vijećem Europske unije, Uvodna riječ predsjednika Vlade, Vlada RH, Zagreb, str.3

/4/ Vlajki E. (2020), Korona, Partija ekonomske i socijalne pravde - PEPS, Banja Luka, str. 35.

/5/ Hrvatski geološki institut, Zagreb, siječanj 2021., https://www.hgi-cgs.hr/ (07.02.2021)

/6/ Plenković M. (1992), Komunikologija masovnih medija, Barbat, Zagreb, str. 123 -125.

/7/ Vlada RH, https://vlada.gov.hr/kako-funkcioniravlada/64

(11.02.2021.)

/8/ Program Vlada, vlada.gov.hr > ZPPI > Dokumenti Vlada ,, Program Vlada, str $32-34$.

19/ Plenković M.(1992), Komunikologija masovnih medija, Barbat, Zagreb, str. 211-227.

/10/ Plenković M.(2020), Information Evaluation of Media Content, Media cult. public. relat. 11, 2020, 1, 1-117 (1 - 4).

/11/ Bastide, R.(2020), Communication Evaluation of Media Content, u: Media cult. Public.relat.Culture and Public Relations, 11, str.118.

/12/ Plenković M.(1989), Prilog strukturiranju komunikologije u Jugoslaviji, u: RTV teorija i praksa, no.57., str. 89-98.

/13/ Kotarbinski T. (1964), Traktat o dobrom delanju, Nolit, Beograd, str.1-189.

/14/ Plenković M. (1980), Demokratizacija masmedija, Biblioteka komunikacijske znanosti, Centar za informacije i publicitet,

Zagreb, str. 97 - 98.

/15/ Plenković M.(1989), Suvremena radiotelevizijska retorika,Teorijska i empirijska analiza, Stvarnost, Zagreb, str.74 -79.

/16/ Turabian K.L. (2013), A Manual for Writers of Research Papers, Theses, and Disertations, Eighth Edition, The University Chicago Press, Chicago and London, p. 5 - 36

/17/ Plenković M,, Mustić D. (2020), Paradigmatic Reflectionns on Media, Culture and Public Relations, u: Informatol. Vol. 53 No. 1-2, 2020. (53 -91). https://doi.org/10.32914/i.53.1-2.5

/18/ Project: "Strategic Communication Management: Paradigmatic Reflektions on Media Culture and Public Relations, Croatian Communication Asociatin \& Alma Mater Europaea \& European Academy of Sciences and Arts, Zagreb, Maribor, Salsburg, $2020-2024$.
/19/ Worldometer, Elaboration of data by of Economic and Social Affairs, Population Division, Medium-fertility variant, 2019. (WPP, 20.03.2021.).

/20/ Adscanner, Lista top 15 najgledanijih televizijskih kanala u periodu od $19-23 \mathrm{H}$ : Svi televizijski zemaljski i nezemaljski kanali, 16.02.2021.

\section{Literatura}

1. Plenković, M., Hadžić, S., Kučiš, M. (2020), Medijska zastupljenost političkih opcija i građansko izborno ponašanje : (case study: Hrvatski parlamentarni izbori 2003. godine). Media, culture and public relations: Mediji, kultura i odnosi s javnostima. 2020, 11, [št.] 1, str. 25-52, ilustr., graf. prikazi. ISSN 1333-6371. https://hrcak.srce.hr/index.php?show=clanak\&id clanak_jezik=345231.

2. Plenković, M., Mustić, D. (2019), Relationship between users age and visual patterns in digital media $=$ Odnos starosti korisnika i vizualne putanje kod korištenja digitalnih medija. Informatologia. 2019, 52, [št.] 3/4, str. 164-172. ISSN 1330-0067. https://hrcak.srce.hr/index.php?show=clanak\&id clanak jezik=341335.

3. Plenković, M. (2017), Holistička komunikativna analiza odnosa s javnostima. Media, culture and public relations : Mediji, kultura i odnosi s javnostima. 2017, 8, [no.] 2, str. 155-172. ISSN 1333-6371. https://hrcak.srce.hr/199661.

4. Plenković, M., Mustić, D. (2016), The new paradigm of participatory communication as a result of participatory culture of digital media. Media, culture and public relations : Mediji, kultura $i$ odnosi s javnostima. 2016, 7, [no.] 2, str. 143-149. ISSN 1333-6371. https://hrcak.srce.hr/176502.

5. Plenković, M., Mustić, D. (2014), Education of journalists and communication scienctists in the Republic of Croatia = Obrazovanje novinara $\mathrm{i}$ komunikologa u republici Hrvatskoj. Informatologia. 2014, vol. 47, no. 1, str. 36-45. ISSN 1330-0067.

6. Plenković, M., Kupinić Guščić, D., Hadžić, S. (2014), Media study on correlation conection between "likes" and "visual elements of form" in communication content perception on Facebook = Medijska studija korelacijske povezanosti dosega "sviđanja" i "vizualnih elemenata forme" u percepciji komunikacijskih sadržaja na Facebooku. Informatologia. 2014, vol. 47, no. 4, str. 243-256. ISSN 1330-0067.

7. Plenković, M., Kupinić Guščić, D., Hadžić, S., Kučiš, M. (2013), Utjecaj multikauzalne pojavnosti 
novih medija i društvenih mreža na empirijsku evaluaciju medijske komunikacije. Media, culture and public relations : Mediji, kultura $i$ odnosi $s$ javnostima. 2013, 4, 2, str. 127-150. ISSN 1333-6371.

8. Plenković, M., Tomažič, T., Kučiš, V. (2010), Holistic strategy of public action and visual digitalization in convergent environment. Observatorio. 2010, vol. 4, no. 2, str. 197-210. ISSN 1646-5954.

http://obs.obercom.pt/index.php/obs/article/view/ 278/352.

9. Plenković, M., Hadžić, S., Kučiš, M. (2006), Dijalektika medijskie moći i izborno građansko ponašanje : (hrvatski parlamentarni izbori 2003) = The dialectics of media power and the electoral behaviour of citizens : (the 2003 general elections in Croatia). Informatologia. 2006, 39, 1, str. 1-21. ISSN 1330-0067.
10. Plenković, M. (2002), Krizno komuniciranje i teorija odnosa $\mathrm{s}$ javnostima $=$ Crisis communication and public relations theory. Media, culture and public relations : Mediji, kultura i odnosi s javnostima. 2002, 1, 1, str. 19-31. ISSN 1333-6371.

11. Plenković, M. (2001), Holistička analiza odnosa s javnostima (javnošću) = Holistic analysis of the public relations. Informatologia. 34, 1-2, str. 27-30. ISSN 1330-0067.

12. Plenković, M., Plenković, J. (1999), Kvalitativna holistička klasifikacija ljudskog znanja i znanosti = Qualitative holistic classification of human knowledge and science. Informatologia. 32, 1-2, str. 26-33. ISSN 1330-0067.

13. Plenković, M., Kučiš, V. (1996/1997), Journalism of tomorrow = Novinarstvo sutrašnjice. Informatologia. 1996/1997, 29/30, 3-4/1-4, str. 155159. ISSN 1330-0067.

\title{
COMMUNICATION INTERPRETATION OF MEDIA CONTENT IN CROATIAN PRESS ON THE GOVERNMENT OF THE REPUBLIC OF CROATIA
}

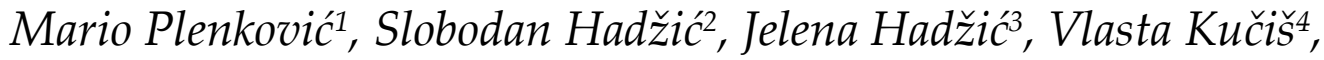 \\ Daria Mustićs \\ University of Zagreb, Zagreb, Croatia \& Alma Mater Europaea - ECM \& Faculty of Electrical Engineering and \\ Computer Science, Institute for Media Communications, University of Maribor, Maribor, Slovenia ${ }^{1}$; PressCut, \\ Zagreb, Croatia ${ }^{2}$; Faculty of Croatian Studies; University of Zagreb, Zagreb, Croatia ${ }^{3}$; Faculty of Arts, University \\ of Maribor, Maribor, Slovenia ${ }^{4}$; Faculty of Graphic Arts, University of Zagreb, Zagreb, Croatia ${ }^{5}$
}

\begin{abstract}
Communicological praxeological evaluation of media content in Croatian newspapers (written visual newspaper content) in relation to the work of the Government of the Republic of Croatia and government institutions, in this research, provided an answer to the question of whether Croatian print media are a mirror of real events or distorted and reshaped reality. The main goal of this longitudinal project research study is to find out how Croatian publications with their (non)critical authorial written and visual contents influence the formation of public opinion among the citizens of the Republic of Croatia about the work and reputation of the Government of the Republic of Croatia. Qualitative and quantitative paradigmatic ontological, epistemological, axiological, rhetorical, statistical and empirical research methodology were used. By choosing a communicological praxeological universal research method of five evaluation variables: (1) objectivity, (2) appropriateness, (3) speed/timeliness of media content, (4) attractiveness and (5) social engagement, in the evaluation of Croatian publications (newspapers and visual production) the basic communicative model of public communication "everyone, with everyone, about everything, fully, argumentatively and personally responsible" at all levels of written and visual newspaper production in Croatian newspapers in the research time limits
\end{abstract}


from January 3rd to February 3rd, 2021 is analyzed. Project research has a longitudinal character (research study no. 1). In this research, the authors present only part of the research project results, which relate to the obtained empirical research results, which relate to the interpretive communication analysis of objectivity, appropriateness, speed (timeliness), attractiveness, and social engagement of newspaper content. The results of segmented empirical research showed a high correlation between newspaper written visual media content on the topic of the Government and the Prime Minister of the Republic of Croatia, and indicate a high extreme representation, in individual publications, with irrational negative newspaper written and visual content.

\section{Keywords}

Communication science, Government of the Republic of Croatia, media, media content, publications, communication interpretation 